\title{
Cocentaina, el pueblo que se rebeló contra su señor por las escrituras del Archivo condal
}

\author{
Antonio Sánchez González ${ }^{1}$
}

Recibido: 26 de abril de 2020 / Aceptado: 22 de febrero de 2021.

Resumen. La noche del 2 de noviembre de 1751 el conde organizó en su villa de Cocentaina una serie de divertimentos para distraer la atención de la población, al objeto de poder sacar durante la madrugada el Archivo del condado con destino a Madrid. Era aquella una época en la que la nobleza concentraba los Archivos de sus estados señoriales como medida acorde con el centralismo borbónico.

De los contenidos de aquel Archivo con las escrituras del condado alicantino de Cocentaina que dio nombre a la comarca del Comtat, trata este artículo, así como de su sistema de organización y descripción documental.

Palabras clave: Condado de Cocentaina; Archivo nobiliario; oposición señorial; traslado de Archivo; centralismo borbónico.

\section{[en] Cocentaina, the people who rebelled against their lord for the scriptures of the condal Archive}

\begin{abstract}
The Count of Cocentaina held a series of festive events during the evening of November 2nd, 1751, with the sole purpose of distracting the people while he was secretly removing the Archivo Condal from the premises and taking it to Madrid. In those times, the nobility centralized their documental archives in Madrid in line with Borbonic centralism. This work aims to produce a detailed study of this archives' contents, which contain a collection of legal documents concerning the Cocentaina county. It will also analyze the structure and organization of the archive and will also provide for a documentary description of the former.
\end{abstract}

Keywords: Cocentaina County, nobility archives, opposition to the lord, removal of archives, Borbonic centralism.

Sumario: Introducción. Casa, linaje y territorio: el condado de Cocentaina, un estado de los Corella valencianos. Formación del Archivo condal. Resistencia del pueblo a la marcha de las escrituras. Agregación a unidades archivísticas superiores. Organización y descripción de la documentación. Conclusiones. Bibliografía. Apéndice. Tabla guía de la sección Cocentaina del Archivo Ducal de Medinaceli.

Cómo citar: Sánchez González, A. (2021). Cocentaina, el pueblo que se rebeló contra su señor por las escrituras del Archivo condal, en Cuadernos de Historia Moderna 46.1, 175-206.

Universidad de Huelva.

E-mail: antonio.sanchez@dhis2.uhu.es

ORCID: http://orcid.org/0000-0001-5025-455X 


\section{Introducción}

Corría el año de 1751 cuando, según testimonio de escribano público relatado algo después por el mercedario fray Agustín de Arques, ocurre un hecho singular. Era el día de los difuntos de dicho año, casi de madrugada, mientras el pueblo participaba en una función teatral, baile y otros divertimentos organizados para la ocasión por los señores del lugar, justo "cuando [los vecinos] estaban más engolfados en la diversión" y, entre ellos, "todos los sujetos principales [de la villa]", cargaron en una recua de mulos los documentos del Archivo de los condes de aquel estado, previamente encajonados, y los sacaron del pueblo camino de Madrid.

Aquel pueblo era Cocentaina, cabecera del condado alicantino del mismo nombre. Y el motivo del traslado de los papeles estaba justificado para el personal de servicio en aquel Palau de la villa: así lo había ordenado el señor conde del lugar, Antonio Benavides y de la Cueva Arias de Saavedra, por más señas también duque de Santisteban del Puerto y otros muchos títulos.

El hecho es que, desde dos décadas atrás, estos señores habían decidido aplicar, con los fondos documentales de sus numerosos estados, una política de concentración archivística en la sede donde tenían fijada la administración y secretaría general, concretamente la casa-palacio que les servía de morada principal en la Villa y Corte, ubicada en la Plaza de San Pedro el Viejo haciendo esquina con la calle del Nuncio. Emulando la política centralizadora borbónica imperante en aquellos momentos, también se aplicaba por entonces en los grandes Archivos nobiliarios españoles desde décadas atrás una política de concentración archivística, al menos en las grandes casas establecidas en la Corte.

En el caso de los Santisteban condes de Cocentaina, la orden de transferencia de papeles fue dada en 1735 por Manuel de Benavides, padre del referido conde, a los administradores de sus respectivos estados, repartidos por gran parte de la geografía peninsular. Y poco después hasta aquel palacio madrileño habían llegado ya todos los fondos documentales de esos dominios excepto uno, el de Cocentaina que aquí nos ocupa.

La espera se hizo larga y los motivos parecen claros. La gente de aquel condado no debió consentir que los documentos que testimoniaban el largo pasado histórico de aquella comarca, que hundía sus raíces en la Edad Media, aspiraba a mantenerlo cerca, rebelándose -llegado el caso- hasta con su propio conde si éste pretendía llevarlo a otro lugar. Sabedor de ello el referido Antonio Benavides, dio la orden de buscar -o forzar- ocasión propicia, para solventar aquel asunto pendiente, finalmente programado aquel día 2 de noviembre de 1751. Para ello hubo de actuarse con nocturnidad ¿y alevosía?, distrayendo la atención de la gente con fiestas, teatro y regocijos populares. Y el plan fue realizado a satisfacción de los ejecutores.

Llegado a Madrid, el Archivo condal contestano quedó incorporado al de la Casa de Santisteban del Puerto, permaneciendo en aquella casa-palacio de la Plaza de San Pedro hasta el siglo XIX en que, formando parte de dicho conjunto archivístico, pasó al majestuoso palacio que los duques de Medinaceli poseían en el madrileño Paseo del Prado, tras unirse por vía matrimonial ambas casas nobiliarias de Santisteban y Medinaceli en el mismo siglo XVIII.

De la rica historia de aquel estado alicantino de Cocentaina, testimoniada en los numerosos pergaminos y papeles del antiguo Archivo condal, nos ocupamos en este trabajo con el objetivo de difundir su contenido, además de perfilar el sistema de 
organización documental de los fondos durante los siglos XVIII y XIX y de trazar su evolución secular hasta nuestros días. Para mejor comprensión, hemos de tratar primero la historia familiar de la rama valenciana del linaje Corella, titulares del condado, hasta agregarse a los Medinaceli.

Para ello, metodológicamente, no solo hemos trabajado en el fondo documental objeto aquí de estudio, revisando sus inventarios y analizando las marcas dorsales de cada pieza documental, sino también en la documentación de referencia que se conserva en la Real Academia de la Historia, preferentemente la colección Salazar y Castro $^{2}$, así como en otras piezas sueltas del Archivo Histórico Nacional, el Histórico de la Nobleza, y los de la Corona de Aragón y el Reino de Valencia ${ }^{3}$.

\section{Casa, linaje y territorio: el condado de Cocentaina, un estado de los Corella valencianos}

Los orígenes de los Corella, como los de tantos otros linajes, echan sus raíces en la misma frontera entre la realidad y la leyenda. Al menos en este caso es muy poco lo que se conoce fielmente de la génesis más remota de la familia. Una versión tradicional, transmitida por diversos genealogistas, remontan la estirpe al legendario Iñigo Barbatuerta, señor de Marcuello y Sos, que llevaba la vanguardia de las tropas cristianas en la batalla de Huesca (1096) y que fallecería en el año 1113 (algunos retrasan la fecha); a su vez, éste sería descendiente de la Casa Real de Navarra como quinto nieto de Iñigo Garcés, hermano del rey Sancho García. De la descendencia directa de este infante, a través del aludido Barbatuerta, surgirían los señores de la villa de Acorella o Corella en el mismo reino de Navarra, un topónimo que dio nombre en adelante a la estirpe ${ }^{4}$.

Poco podemos asegurar, al respecto de este regio origen y de semejante ascendencia familiar, por ausencia de testimonios documentales ${ }^{5}$. Lo que sí se puede aseverar con fundamento es que, de la villa navarra de Corella, acompañaron algunos ricoshombres al rey Jaime I de Aragón en la conquista de la ciudad y de todo el reino de Valencia. Uno de ellos - afirma Diago- fue Pedro Rois o Ruiz de Corella, señor de Corella, que ya se halló con el rey aragonés en la conquista de Burriana en 1235,

\footnotetext{
Se transcriben, dentro de esta colección de la Real Academia de la Historia (RAH, Col. SyC), varias decenas de documentos sobre los condes de Cocentaina, algunos de ellos citados en este trabajo.

Algunos documentos de estos Archivos, de interés para nuestro estudio, también se citan en este trabajo.

4 Ésta y similares versiones genealógicas, todas ellas conducentes a enlazar a los Corella con la Casa Real de Navarra a través de algunos de sus infantes, aparecen por ejemplo en Escolano, G.: Décadas de la historia de la ciudad y reino de Valencia, Valencia, 1879, libro XI cap. XLV - "De la antigua villa de Cocentaina y del linage y caballeros señalados del apellido de Corella", tomo II, pp. 586-590; Salazar y Castro, L.: Historia genealógica de la Casa de Lara, tomo III, Madrid, 1697, p. 149; y, con mayores recatos, en Diago, F.: Anales del Reyno de Valencia, Valencia, 1613, cap. XIII, fol. 298. Por nuestra parte, hemos incluido en la genealogía Cocentaina $=$ Corella $=$ que ilustra este trabajo (tabla 1), aún con mayores reservas, estos orígenes más remotos e indocumentados del linaje. Salvo las cuatro primeras generaciones, por tanto, dicha tabla genealógica recoge más fielmente la evolución de la estirpe de los Corella, titulares del condado alicantino de Cocentaina a partir de mediados del siglo XV.

5 A este respecto, desmontando mitos, lo mejor documentado a la vez que actualizado, es la obra reciente de Richart Gomá, J.: Los Corella, Condes de Cocentaina. Memoria histórica de su linaje (Siglos XIII-XVII), Alcoy: Ayuntamiento de Cocentaina, 2019, pp. 17-46.
} 
iniciadora de la recuperación del reino valenciano ${ }^{6}$. Este Pedro, en compensación, obtuvo como repartimiento los castillos de Pedreguer, Almusafes, Gata y otros lugares de aquellos recién conquistados ${ }^{7}$, siendo el verdadero tronco de la Casa Condal de Cocentaina y de la mayor parte de los Corella valencianos. Casó con Beatriz Castellà y de Llançol, de la que tuvo como heredero a Atón Orella (Atorella) Ortiz de Corella, o Antonio Ruiz de Corella, que acompañó a Jaime II en todas sus campañas, recibiendo del monarca como recompensa el castillo aragonés de Moçalbarba ${ }^{8}$. Sus inmediatos descendientes hasta los albores del siglo XV debieron seguir gestionando los heredamientos conseguidos tras la conquista del reino levantino. Pero el encumbramiento del linaje navarro afincado en la región valenciana se iba a producir en el segundo cuarto de esa centuria cuando asume la jefatura de la Casa Ximén Pérez de Corella (1400-1457), hijo de Juan Ruiz, señor de Corella9.

Ximén fue uno de los capitanes que tuvo el rey Alfonso V de Aragón (III de Valencia) en sus campañas expansivas por el Mediterráneo ${ }^{10}$. Su relevante papel militar en favor de la Monarquía aragonesa, del que se hace eco Jerónimo de Zurita en varios capítulos de sus Anales, comienza a desarrollarse en 1420 acompañando al monarca en sus incursiones a las islas de Córcega y Cerdeña, que habían caído en poder de los genoveses ${ }^{11}$, y en el asalto de Marsella y la conquista de la isla de Djerva o Gelves contra el rey de Túnez ${ }^{12}$, campañas en las que sobresalió Ximén Corella por su valor y destreza en el campo de batalla ${ }^{13}$. Particularmente se había distinguido en el asalto a la plaza corsa de Bonifacio (1421), que le dio prestigio ${ }^{14}$.

E incluso en el asedio de Nápoles por parte de las tropas de Luis III de Anjou, mandadas por Muzio Sforza en 1423, cuando Corella acompañaba a Alfonso V a socorrer a la reina napolitana Juana II, y a pesar de caer prisionero como su monarca, reconoce el propio Zurita que Ximén Pérez peleó bravamente, refiriéndose a él como "... señalado caballero que hizo oficio de gran soldado, como lo pudiera hacer el más valiente capitán que se hallara en su lugar y, poniéndose por los enemigos a caballo, hizo aquel día hazaña de gran caballero" $" 15$.

Estos servicios militares fueron recompensados por el rey de Aragón con el nombramiento de Ximén Corella como gobernador o virrey del reino de Valencia a partir de 1429, una lugartenencia que desempeñaría durante casi toda su vida, aunque fuera sustituido en sus largas ausencias por diversos personajes, caso de Romeo de Corbera, Pedro de Urrea, señor de Alcalatén, y su propio hijo Juan Ruiz de Corella ${ }^{16}$.

Diago, op. cit. (nota 4).

Ibidem.

Fullana Mira, L.: Historia de la Villa y Condado de Concentaina, Valencia, 1920, p. 264.

Véase Martín de Viciana, R.: Crónica de la ínclita y coronada ciudad de Valencia, Valencia, 1564 [1972], $2^{\mathrm{a}}$ parte, p. 103 y Fullana, ibidem., pp. 265.

Fullana, op. cit. (nota 8), p. 265-268

Ibidem., p. 264.

2 Zurita, J.: Anales de la Corona de Aragón. Zaragoza: Lorenzo de Robles, impresor, 1610-21 (edic. Instituto Fernando el Católico, Zaragoza, 1970-1975): libro XIII, cap. XXII.

13 Ibidem.

14 Zurita, op. cit. (nota 12), lib. XIII, cap. VIII. Dice el analista al respecto: "la valentía, esfuerzo y gran valor de Ximén Pérez de Corella fue muy conocido y estimado en aquellos tiempos".

15 Ibidem.

16 Archivo de la Corona de Aragón (ACA), Reg. 2943, fol. 30 y Archivo del Reino de Valencia (ARV), Real Cancillería, Lib. Officialium, 419, fols. 46 v y 113-115. Véanse Martín de Viciana, op. cit. (nota 9), p. 103; Fullana, op. cit. (nota 8), p. 269; y Mateu Ibars, J. Los virreyes de Valencia. Fuentes para su estudio, Valencia, 1963, pp. 89-90. 
En 1432, el virrey valenciano era nombrado por el monarca capitán de su armada en la expedición que hizo la Corona aragonesa al norte de África ${ }^{17}$.

Por el tratado de Milán, en 1435 entre el duque de Milán y Alfonso V se llegó a un acuerdo de división en las empresas italianas: todo el norte (incluida Córcega, a la que renunció el aragonés), quedaría bajo la influencia milanesa, mientras que el sur de Italia -especialmente el reino de Nápoles- se convertía en área de expansión de la Corona de Aragón. Tan interesado estaba el rey Magnánimo en ese "sueño napolitano" que, desde su base de Gaeta, Alfonso V fue paulatinamente limando el poder angevino en Italia y ganando adeptos. Las conquistas de Aversa (1440) y de Benevento (1441) fueron el preludio del largo asedio de Nápoles por parte de la armada y del ejército aragonés.

Sirviendo como consejero del rey en Italia desde 1434, también se distinguió Ximén de Corella en el asalto y conquista de Nápoles en junio de $1442^{18}$. La nobleza del reino aceptó entonces al nuevo rey como soberano, comprometiéndose este al pago de un elevado donativo en metálico como sufragio a los elevados gastos de la guerra. El 14 de junio de ese año 1443 se firmaba la paz de Terracina, por la que el papa Eugenio IV, antes ferviente partidario de Renato de Anjou, reconoció el gobierno sobre Nápoles de Alfonso V, quien completaba así la rotunda victoria contra todos sus enemigos.

En recompensa a la valiosa contribución que Ximén Pérez le dispensó a su rey, Alfonso V le proporcionó la facultad especial de hacer uso de las armas reales de Aragón y Sicilia en su blasón familiar, preferentemente para perpetuar así la hazaña napolitana del valeroso capitán Corella. Además, por el mismo privilegio, el rey le concedía una subvención anual vitalicia de 3.000 ducados de renta ${ }^{19}$, de modo que atesoró en su época una de las mayores fortunas del reino de Valencia ${ }^{20}$.

Ésta y otras contraprestaciones salidas de las arcas regias para pagar a los deudores que tenía la Monarquía aragonesa obligaron al rey Magnánimo a vender a Ximén Pérez de Corella la villa y baronía de Cocentaina, en el propio reino valenciano, con título de condado, por precio de 80.000 florines de oro, en escritura de compraventa dada por el monarca en Torre de Octavio (Nápoles) el 28 de agosto de $1448^{21}$. Previamente, el 9 de septiembre de 1447, Ximén había comprado al monarca el lugar de Dos Aguas por importe de 230.000 ducados de moneda valenciana ${ }^{22}$.

Zurita, op. cit. (nota 12), libro XIV, caps. III-IV.

18 Escolano, G., op. cit. (nota 4), lib. IX, Cap. XLV; Facio, B.: Historia de Alfonso V, Lyon, 1560; y Bonincontri, L.: Historia Regni Neapolitani, libri X. BHUV, ms. $n^{\circ} 689, \mathrm{~S}$. XV. Véase Ryder, A., El reino de Nápoles en la época de Alfonso el Magnánimo, Valencia, 1987, pp. 82-84.

19 Fullana, op. cit. (nota 8), p. 267 (fuente: ARV, Justicia Civil, Manaments y Empares, tomo VI, fol. 418). Cfr. Martín de Viciana, op. cit. (nota 9), p. 140.

20 Véase López Rodríguez, C.: Nobleza y poder político en el reino de Valencia (1416-1446). Valencia: Universitat de València, 2005.

21 Archivo Ducal de Medinaceli (ADM), Cocentaina, 1-31, documento transcrito y traducido del latín por Fullana, op. cit. (nota 8), pp. 276-288. La carta de pago, fechada el 7 de septiembre inmediato, en ADM, Cocentaina, 1-32, documento reproducido por Richart, op. cit., (nota 5), p. 112

22 ARV, Real Cancillería, Registro 2913, fol. XXVI. 


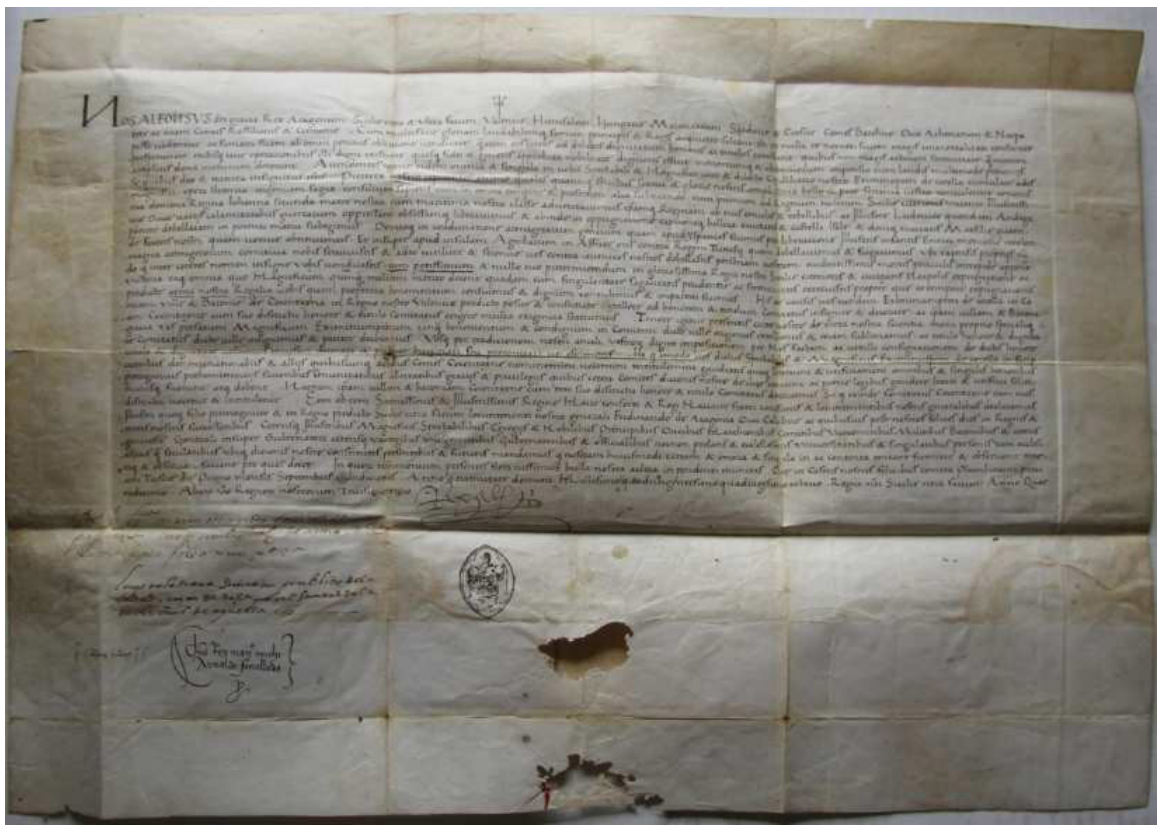

Fig. 1. Título, en pergamino, de primer conde de Cocentaina a Ximén Pérez de Corella (1448). Falta el sello de oro que lo validaba (Archivo Ducal de Medinaceli)

Y para que la merced a su consejero y camarlengo fuera aún más solemne, tres días después de la venta de la baronía contestana expidió el propio Alfonso $\mathrm{V}$ un nuevo privilegio, que autorizó con su sello de oro pendiente, reconociendo a Ximén Pérez de Corella como primer Conde de Cocentaina. El documento fue otorgado por el monarca "cerca de Pomblin [Piombino]", lugar y puerta marítima a la Toscana, el 1 de septiembre de 1448 (fig. 1) ${ }^{23}$.

El flamante conde retornó después a la Península, en 1450, para administrar su estado levantino de Cocentaina, antigua posesión del almirante aragonés Roger de Lauria y de sus descendientes ${ }^{24}$, además de otros dominios próximos que poseía -las villas, lugares y castillos de Elda, Aspe, Petrer y Salinas ${ }^{25}$ - y también para hacerse cargo del gobierno del reino valenciano en calidad de virrey, cargo que durante su ausencia había ocupado mayoritariamente su primogénito ${ }^{26}$. A ello dedicó los que ya

23 ADM, Archivo Histórico (Títulos), leg. 272 núm. 19 (A.- doc. original). Concurren en esta merced real circunstancias excepcionales como la entrega del anillo regio por parte del monarca, la consignación del estandarte, aparte la validación del documento con sello de oro, que falta.

24 Efectivamente, la musulmana Qustantaniya, conquistada por Jaime I en 1245, había sido entregada por Pedro IV en 1291 al almirante de la flota de la Corona de Aragón y de Sicilia Roger de Lauria (1245-1305), en recompensa a su trayectoria militar al servicio de la Corona aragonesa, pues dirigió brillantemente la flota durante todo el reinado de Pedro III el Grande. Como señor de aquel lugar, Roger de Lauria construyó en Cocentaina su alcázar, convertido más tarde, por los Corella, en palacio condal.

25 En 1431 Ximén había adquirido el lugar de Petrer, por vía de compraventa, de Pere de Rocafull (ARV, Real, reg. 495, fols. 504-511). Previamente en 1424, con autorización de Alfonso V, había comprado a la reina Violante los valles de Elda y Aspe por un coste de 43.650 libras barcelonesas. En tales términos quedaban incluidos los señoríos del mismo Petrer y de Salinas. Véase Fullana, op. cit. (nota 8), pp. 270-271.

26 ARV, Lib. Officialium, 419 fol. CXV. Véase Fullana Mira, L.: Los Virreyes de Valencia, [Valencia, 1916], pp. 250- 253 (una genealogía desde el primer conde hasta la condesa Antonia de Corella y Dávila en p. 252). 
serían los últimos años de su vida hasta poco antes de su muerte, en que regresó a Nápoles, donde falleció el 17 de octubre de $1457^{27}$.

Casado en Valencia desde 1414 con Beatriz Llançol de Romaní, de las familias de los señores de Vilallonga y de Agres $^{28}$, el matrimonio tuvo varios hijos, sucediendo al primer conde el primogénito Juan Ruiz de Corella (c.1417-1478) (9 $^{29}$ y, sucesivamente, sus descendientes en línea de primogenitura, quienes ejercieron durante el siglo XVI notables papeles como capitanes generales de Nápoles, Sicilia o Valencia y destacaron también en campañas como la revuelta de las Germanías ${ }^{30}$.

A comienzos del siglo XVII los condes de Cocentaina ostentaron, además, efímeramente el condado de la Puebla del Maestre como consecuencia del matrimonio contraído en 1601 entre Gastón Ruiz de Corella (†1611), VII Conde, y su prima hermana, la V Condesa de este estado pacense Brianda de Cárdenas y Corella (c.1583$1604)^{31}$. La muerte, siendo aún niña y sin descendencia, del único vástago de este matrimonio, Guiomar de Corella y Cárdenas (1604-1613), titular de ambos estados desde $1609^{32}$, propició que se separaran en adelante, de nuevo, los dos condados ${ }^{33}$. Pues, aunque la pequeña poseyó el mayorazgo de la Puebla desde su nacimiento, pues su madre murió en el parto, fue desposeída de él por sentencia de 1611 que ganaba un primo de su abuelo, Luis de Cárdenas y Toro.

27 Fullana, op. cit. (nota 8), p. 309-310. Narra el autor todos los detalles y pormenores de la postrera enfermedad del conde y de sus últimas voluntades en testamento nuncupativo.

28 Richart, op. cit., (nota 5), p. 90.

29 Richart refiere también la legitimación por el monarca en 1450 de los 11 hijos bastardos que tuvo (ibidem, p. 116). Ximen llegó, además, a adoptar una hija del rey llamada Beatriz (ibidem, p. 122). La biografía del segundo conde en ibidem, pp. 127-158.

30 Véase la evolución familiar en tabla 1 (genealogía Cocentaina $=$ Corella $=$ ).

31 Véase RAH, Col. SyC, M-15, fols. 175 y 175 v., núm. 48600 del inventario (Cuartero Huerta, B. y Vargas Zúñiga, A. de -Marqués de Siete Iglesias-: Índice de la Colección de don Luis de Salazar y Castro. 49 vols. Madrid, 1958-1974).

32 Memorial del pleito entre las partes (s.f. ¿1613?), véase RAH, Col. SyC, X-22, fols. 66 a 97, núm. 72868 del inventario. Véanse también los núms. 72810 a 72815.

33 Memorial del pleito entre las partes litigantes, 1612. RAH, Col. SyC, U-4, fols. 291 a 322, núm. 71652. 


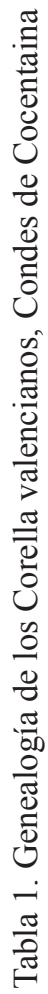
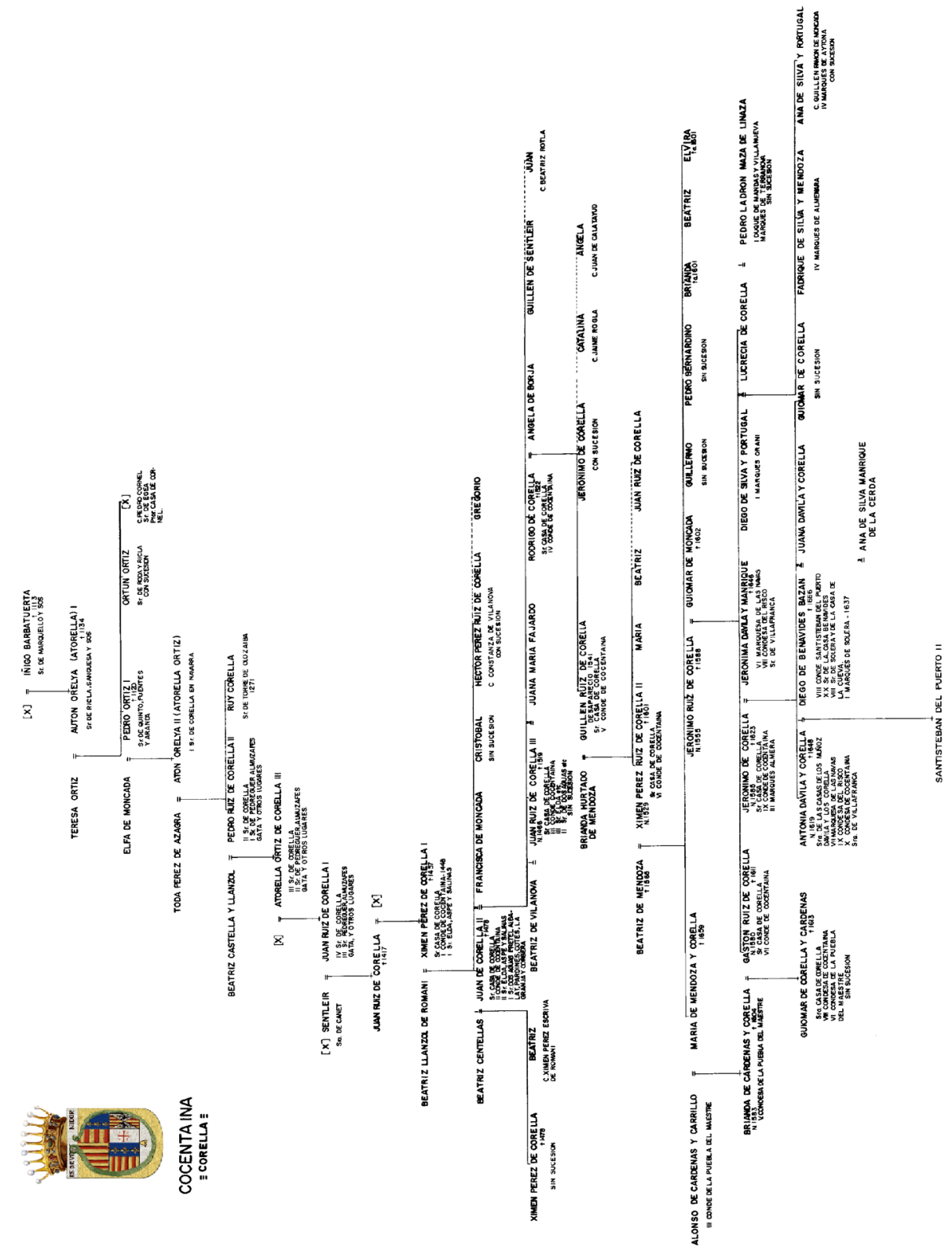
Ese mismo año, por muerte de su padre, Guiomar sucedió en la casa y estados de Cocentaina, pero efímeramente, pues moría niña poco después, el 2 de marzo de 1613, aún sin cumplir los diez años.

Fueron aquellos unos años difíciles para aquel condado de cristianos viejos en un mundo morisco por las repercusiones que se dieron en la comarca como consecuencia de su expulsión ${ }^{34}$, decretada en 1609 , que dejó diezmada toda la comarca de población ${ }^{35}$.

El estado alicantino recayó, en 1613, en Jerónimo de Corella (†1623), como tal, IX Conde de Cocentaina, a cuyo dominio incorporó en 1614 la aldea de Fraga de los Abades por compra al prior del monasterio de San Miguel de los Reyes, extramuros de Valencia, con un coste de 25.000 libras $^{36}$.

Quedaba así configurado definitivamente el territorio de aquel condado ocupando la mayor parte de la zona que, de este estado, recibió el nombre de comarca del Comtat, al norte de la actual provincia de Alicante lindando con la Valencia por las comarcas de la Vall d'Albaida y la Safor. Por el este circundaba el condado esta misma comarca de Safor y las de Marina Alta y Baja, ésta última dándole además límite meridional. Por el oeste tenía la comarca de L'Alcoià y parte de la Vall d'Albaida. Este territorio se hallaba así situado en el extremo del prebético oriental ya en las proximidades del Mediterráneo, donde quedan las sierras de Mariola, Almudaina, Serrella, Alfaro, Aitana y Benicadell. El condado está cursado por las aguas del Serpis, Penáguila o Fraimós, Ceta y Agres. La extensión superficial del condado superaría los 250 kilómetros cuadrados y sus perfiles quedan recogidos en el mapa (fig. 2). La capital del estado, Cocentaina, quedaba situada en la margen izquierda del Serpis, en la vertiente este de la sierra de Mariola a la falda del cerro de San Cristofol.

34 Cocentaina tenía entonces una población aproximada de 1.600 habitantes y un arrabal morisco, la antigua morería, de población algo menor, pero con personalidad administrativa propia y autoridades locales independientes a las de la villa. Más datos en estas estas obras de Pla Alberola, P.J.: "Los movimientos migratorios en el condado de Cocentaina tras la expulsión de los moriscos", en Estudis sobre la població del País Valencià: Actes de les I Jornades d'Estudi sobre la Població del País Valencià, vol. 1, 1988, pp. 301-314; "Las rentas señoriales del condado de Cocentaina en vísperas de la expulsión de los moriscos", en Actas del V Simposio Internacional de Mudejarismo, 1991, pp. 275-288; "El régimen municipal en las cartas pueblas del condado de Cocentaina, 1611", Dels furs a l'estatut: Actes del I Congrés d'Administració Valenciana, de la Història a la Modernitat, Valencia, 1992, pp. 511-517.

35 Silvestre Pérez, S.: El procés repoblador postmorisc al comtat de Cocentaina: entre la mobilitat $i$ la consolidació. Tesis Doctoral: Universidad de Valencia, 2019.

36 ADM, Cocentaina, 8-20 a 24. Véanse Fullana, op. cit. (nota 8), p. 402, y Pla Alberola, P.J.: "Fraga, un señorío eclesiástico en el S. XVI", Alberri, 27 (2017), pp. 117-177. 


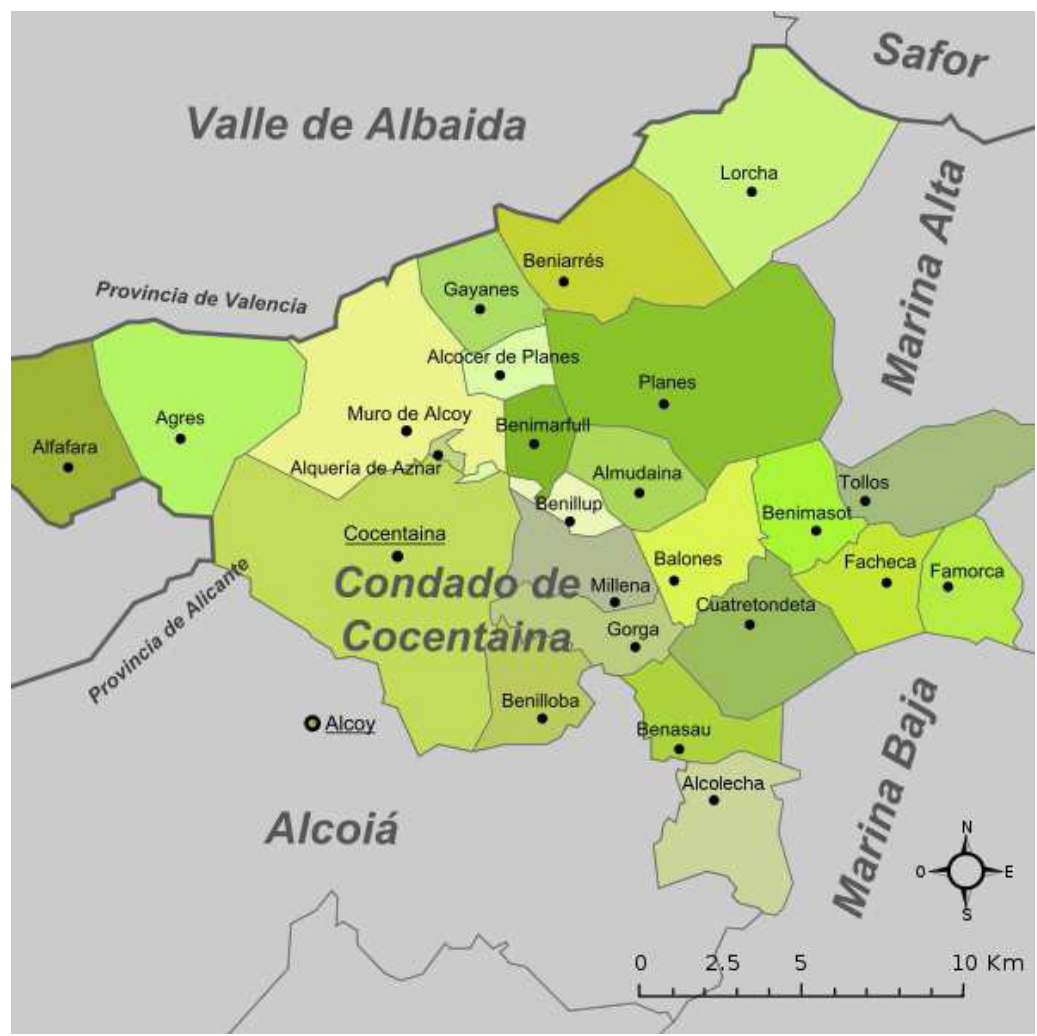

Fig. 2. Mapa de la comarca del Condado

Fuente: https://upload.wikimedia.org/wikipedia/commons/b/be/Mapa_del_Condado_de_ Cocentaina.svg [Consulta: 30/03/2020]

Amplió, además, Jerónimo de Corella el patrimonio señorial de su Casa a costa del marquesado de Almenara al ganar el pleito que desde tiempo atrás sostenían los Corella con los duques de Pastrana y príncipes de Melito. Sin embargo, se trató de una ampliación patrimonial vitalicia por cuanto, a su muerte, acaecida en Milán el 22 de octubre de 1623, el estado de Almenara hubo de pasar a su sobrino Fadrique de Silva y Mendoza, al ser de rigurosa agnación, ya que él solo dejaba descendencia masculina ${ }^{37}$.

Antes de esto, el mismo IX Conde de Cocentaina Jerónimo posibilitó la ampliación futura de los dominios de la Casa -que en este caso sí iba a hacerse efectivapor el casamiento que había contraído en 1615 con Da . Jerónima Dávila Manrique $(\dagger 1646)$, una señora que se convertiría -ya viuda de aquel- en VI Marquesa de las Navas, VIII Condesa del Risco y señora de Villafranca de la Sierra, estados todos abulenses, en herencia paterna.

Al carecer el matrimonio de descendencia masculina, el condado de Cocentaina recaía en 1623 en Antonia de Corella y Dávila (1619-1648), la mayor de las hijas ${ }^{38}$.

ADM, Cocentaina, 10-32 y 33. También sobre estos pleitos hay varios documentos en RAH, Col. SyC, núms. 72810 a 72814. Véase Fullana, op. cit. (nota 8), p. 401.

38 Fullana, ibidem, p. 405-406. 
Ella, además, sucedería en los estados maternos, tras la muerte de Jerónima en 1645, añadiendo a su título de X Condesa de Cocentaina los de VII Marquesa de Las Navas, IX Condesa del Risco, señora de Villafranca y la dignidad de Alférez mayor de la ciudad de Ávila.

Tres años más vivió la aludida Antonia de Corella por lo que, en 1648, todo su patrimonio se incorporó a la Casa de los condes de Santisteban del Puerto con motivo del matrimonio que, en 1630, había contraído con Diego de Benavides Bazán y de la Cueva (1607-1666), por entonces Marqués de Solera, como heredero de esta Casa, y ahora su titular como VIII Conde de Santisteban ${ }^{39}$.

Tras una sucesión efímera en los estados maternos del primogénito Pedro de Benavides (1642-1659), XI Conde de Cocentaina y demás títulos, que falleció soltero en Irún cuando era muy joven, siguió en la jefatura de la Casa el segundogénito Francisco de Benavides Dávila y Corella IV (1645-1716), quien gestionó los aludidos estados maternos a partir de 1659, y siete años después, a la muerte de su padre en Lima, se convertía en el IX Conde de Santisteban del Puerto además de XII Conde de Cocentaina, etc ${ }^{40}$. El nuevo conde prestó grandes servicios a la Monarquía española, tanto cuando obtuvo la capitanía general del reino y costa de Granada (1672) como en el desempeño, sucesivamente, de los virreinatos de Cerdeña (1675-1678), Sicilia (1678-1687) y Nápoles (1687-1695), por lo que fue reconocido y tratado, desde 1696, como Grande de España ${ }^{41}$. Y con él se atravesaba el siglo XVIII, a partir de 1716 con la jefatura del decimotercero de los 17 hijos que tuvo el conde Francisco, llamado Manuel de Benavides y Aragón (1682-1748), quien por vía matrimonial ampliaría también los estados de la Casa con el marquesado de Malagón, los condados de Castellar y Villalonso y un conjunto de señoríos como los de Paracuellos y El Viso.

\section{El archivo condal: formación y estancia en el condado}

El Archivo Condal contestano desde sus orígenes estuvo emplazado en la villa cabecera del estado, dentro de aquella antigua fortaleza que Roger de Lauria edificó a mediados del siglo XIII sobre un antiguo edificio musulmán y que quedó luego convertida en palacio durante la segunda mitad del siglo XV cuando aquel territorio se convierte en condado bajo la jurisdicción de la familia Corella. Es entonces cuando se realizan las grandes obras de reforma y ampliación del inmueble que le dan el aspecto que aún vemos en nuestros días.

El edificio forma parte del recinto amurallado de la villa medieval ${ }^{42}$ y su apariencia es el de un palacio gótico-renacentista, de planta cuadrada, que gira alrededor de

39 ADM, Santisteban, 10-40. Véase Sánchez González, A.: El Archivo de los Caudillos Mayores del reino de Jaén (Casa de Santisteban del Puerto). Jaén: Instituto de Estudios Giennenses, 2015, pp. 50-53 y genealogía en apéndice final. Este conde Diego Benavides elevó al rey un memorial con noticias históricas sobre la grandeza de su Casa (Pellicer de Tovar, J.: Memorial de Diego de Benavides al rey. Madrid, 1640).

40 También elevó al rey el conde Francisco un memorial sobre la grandeza de su Casa (Vidania, D. V. de: Memorial de Francisco de Benavides al rey de los servicios de su Casa. Nápoles: Imprenta de D.A. Parrino y M.L. Mucio, 1696).

41 Véase Guía Oficial de Grandezas y Títulos del Reino (edic. 2009), p. 51. El memorial de solicitud de la Grandeza en RAH, Col. SyC, D-63, fols. 61 a 88, núm. 30863. Véase Sánchez, op. cit. (nota 39), pp. 53-58.

42 La Vila medieval cristiana de Cocentaina estaba cercada por un recinto amurallado con veinticuatro torres y cuatro portales de entrada. Véase Nadal, V.: "Una vila fortificada: les muralles medievals de Cocentaina", en 
un patio de finales del siglo XVI, aunque se realizó solo la galería del lado sur, con columnas toscanas, en obra atribuida a Alonso de Covarrubias ${ }^{43}$. Su carácter defensivo se constata en sus tres torres, siendo en la primera planta de la torre de homenaje donde se encuentra la llamada "Sala Dorada", con bóveda de crucería estrellada de terceletes, decorada con frescos del siglo XVII con temas referidos a los reyes de Navarra, como quedó dicho, presuntos ascendientes de estos Corella valencianos ${ }^{44}$, sin duda, el más importante conjunto de la pintura mural genealógica de la Comunidad Valenciana, que fue realizado entre 1613 y 1623 por el pintor Gerónimo Rodríguez de Espinosa, con ayuda de su hijo Gerónimo Jacinto de Espinosa.

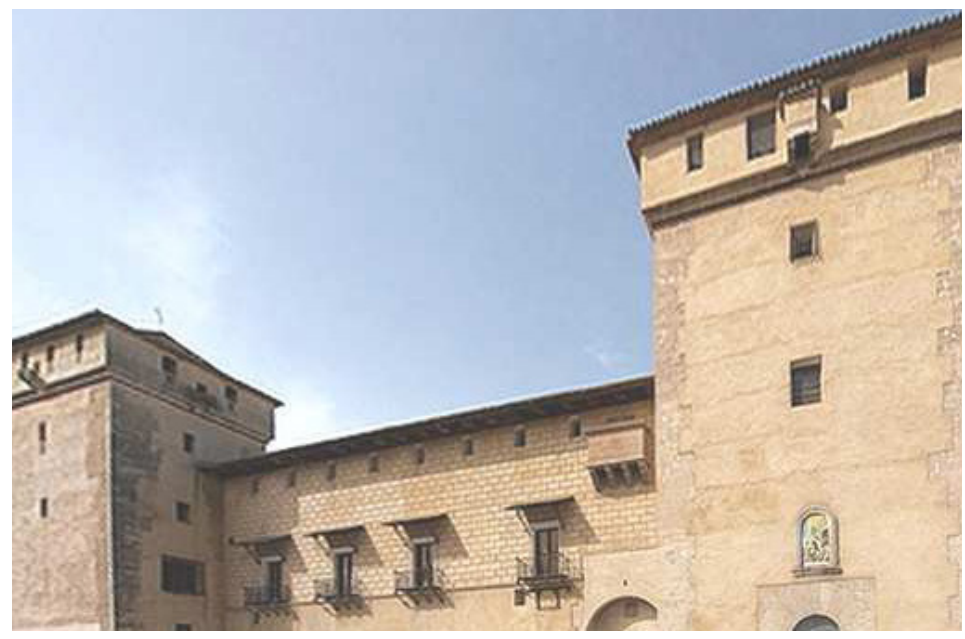

Fig. 3. Fachada del Palau condal de Cocentaina.

El antiguo Archivo ocupaba la primera planta del torreón derecho

Conocemos la ubicación exacta del Archivo Condal, dentro del inmueble, al menos durante la primera mitad del siglo XVIII, situado exactamente "en la pieza que hay encima de la portería y torno del convento" de monjas clarisas ${ }^{45}$ que el conde Diego de Benavides había fundado a mediados del siglo XVII y se labró en el ala norte del edificio palaciego en las décadas siguientes ${ }^{46}$.

Cocentaina: arqueología y museo: Museos Municipales en el MARQ, 2015, pp. 230-241; y Ferrer i Marset, P.: El Comtat. Una terra de castells. Cocentaina: Centre d'Estudis Contestans, 1996, pp. 22-35.

43 Cristini, V. y Martella, F.: "Palacio condal de Cocentaina, Alicante (1979-2013)", en Mileto, C. y Vegas, F. (eds.), La restauración de la tapia en la Península Ibérica: criterios, técnicas, resultados y perspectivas, Valencia : TC Cuadernos, 2014, pp. 186-189.

44 Evidentemente esta representación de tales ascendientes regios de los Corella pintada en el artesonado de esta majestuosa sala del palacio condal, situada en el piso principal de la torre del homenaje, es una prueba evidente de que estos condes tenían más que asumida su ascendencia de la Casa Real navarra. Las nervaduras de la bóveda dejan trece espacios, en los que están pintados al óleo los primeros Reyes de Navarra, el enigmático escudo de armas de los Corella y otros símbolos heráldicos, como la serpiente con cabeza de mujer. Véase Hernández Guardiola, L.: "Las pinturas de la sala daurada del Palau Comtal de Cocentaina", Alberri: Quaderns d'investigacio del Centre d'estudis contestants, 20 (2010), pp. 203-216.

45 Archivo Parroquial de Santa María de Cocentaina (APSMC), Papeles Varios (Arques Jover), s/sign. Una reproducción, en estado actual, de este pequeño depósito en Richart, op. cit., (nota 5), p. 165.

46 El convento ocupa ese sector septentrional del palacio y forma una unidad con el mismo, aunque se le habilitó de acceso particular. Se desarrolla alrededor de un patio y un huerto, donde se disponen las diferentes depen- 
Por entonces estos nobles aplicaban en sus depósitos archivísticos una política de descentralización, considerando que los documentos debían estar lo más próximos posible a los bienes y derechos que administraban (razón por la que tenían archivos en cada uno de sus principales dominios).

Pero traspasado el siglo XVIII esta política cambió, en emulación del imperante centralismo archivístico que promueven los Borbones ${ }^{47}$ para la búsqueda y recopilación de documentos que justificasen la recuperación de bienes enajenados del Patrimonio Real. Ello arranca con la Junta de Incorporación creada por Felipe V en Decreto de 21 de noviembre de 1706, para la reintegración a la Corona de su patrimonio previamente enajenado, previniendo la obligación para todo titular de las rentas reales, de los oficios públicos y de los demás derechos enajenados de la Corona de presentar los títulos que justificaran su posesión ${ }^{48}$. Este proceso centralizador borbónico tiene, además, como otros hitos el Auto Acordado de 1720 sobre la interpretación del testamento de Enrique IV -en cuyo contexto aparece el Informe de Santiago Agustín Riol sobre el mal estado de los archivos españoles ${ }^{49}$, al que los Borbones intentan poner orden-, así como el Decreto de 18 de noviembre de 1732 para la aplicación de la redención de juros al desempeño de las alcabalas, tercias y otros derechos. Algo más tarde se crearon las Comisiones de Archivos para la búsqueda de documentos en que basar el regalismo, tema ya estudiado por Gloria Aparicio demostrando, efectivamente, la relevante labor de localización de fondos, recopilación y compulsa do-

dencias. Su iglesia, de escasa relevancia exterior, tiene en su interior abundante decoración barroca; es de planta rectangular de una sola nave con dos capillas laterales dispuestas en la mitad de la nave y está cubierta con bóveda de cañón con lunetos, y alberga un conjunto de pinturas de Paolo Matteis (1696), más la tabla de la Virgen del Milagro de estilo gótico internacional (véase Jaén i Urban, G. -dir.-: Guía de Arquitectura de la Provincia de Alicante, p. 134; más datos en Vidal Bernabé, I.: "Patronato de los Condes de Cocentaina en el Convento de la Virgen del Milagro", en Patronos, promotores, mecenas y clientes: VII CEHA, Murcia: Universidad de Murcia, 1992, pp. 403-412).

47 Estos monarcas crearon en Madrid distintos Archivos, como el de la Cámara de Castilla, el del Consejo de Castilla en la Casa de los Consejos, los Archivos de las Secretarías de Estado y de Despacho, el de las Contribuciones Generales en la Casa de Aduanas o el Archivo del Tribunal Mayor de Cuentas, entre otros [Gaite Pastor, J.: "El sistema de archivos de la administración central española", Revista General de Información y Documentación, vol. 9, n. 2 (1999), pp. 128-129]. Pero, sin género de dudas, la gran concentración archivística de los Borbones fue la creación del Archivo General de Indias en Sevilla, en 1787, que reunió todos los papeles de las administraciones públicas metropolitanas relativas a América. Se trata del segundo fenómeno de concentración de fondos documentales que se da en Europa, con precedentes en el archivo de Hanover (1713), los archivos de la casa de Saboya en Turín, que el monarca cuidará personalmente, o los de Rusia, obra de Pedro el Grande (1720), y cuyo máximo ejemplo fue el Archivo Imperial de Viena (Hans Hof und Staatarchiv), promovido por la emperatriz María Teresa (1749) [López Gómez, P.: “Archivística y archivos en España. De práctica tradicional a teoría científica”, Archivní časopi, 65 (2015), p. 8. Sobre este modelo austríaco, aparecerán después los depósitos de Buda para el reino de Hungría, y de Milán para el reino lombardo-véneto. También se seguirá en Varsovia (1765), Venecia (1770), Florencia (1778) y en la Escocia de 1787 en la Register House de Edimburgo (creada en 1774) [López Gómez, P.: "Política archivística y concentraciones de archivos en España, en el siglo XVIII", en Vaquinhas, N.; Caixas, M.; Vinagre, H. (eds.), Da produção à preservação informacional: desafios e oportunidades, Évora: Cidehus, 2017, p. 69 § 48].

48 La monarquía borbónica precisamente se interesó con los documentos de archivo por su relación directa con el conflicto de las regalías, que dio lugar a un buen número de pleitos con la nobleza y el clero. Ambos estamentos también hicieron uso de sus documentos con el fin de conservar sus propiedades y para elaborar la historia de las casas nobiliarias, como hicieron estos Benavides, condes de Santisteban y de Cocentaina.

49 Riol, S. A.: Noticia general de todos los archivos y papeles pertenecientes a los Consejos y Audiencias de España. Escrita por orden del rey Felipe V, Madrid, 1726. De esta obra, de la que se conservan varios manuscritos con diferencias entre sí, se hizo una impresión en el Semanario Erudito de Valladares, tomo 3, Madrid, 1787, pp. 74-236. 
cumental llevada a cabo por los comisionados en los archivos eclesiásticos, civiles y particulares de los obispados a los que fueron destinados, que revela la inmensa masa documental recopilada de los papeles más interesantes conservados en sus archivos, los manuscritos que recuperaron y las obras históricas que elaboraron, siguiendo las detalladas instrucciones emanadas de la Secretaría de Estado ${ }^{50}$.

En aquel emplazamiento del Palau condal se encontraban los fondos del condado de Cocentaina cuando el 2 de agosto de 1735 el conde Manuel Benavides emite una orden desde Nápoles para que los administradores de sus estados (bajo cuya custodia aún permanecían la documentación de los archivos de sus respectivos dominios señoriales) remitiesen las escrituras a Madrid ${ }^{51}$. De conformidad con la orden recibida, el contador mayor o apoderado general de la Casa cursó oficios, el día 27 de agosto de 1735, a los tres administradores afectados: Pedro de Lago (del condado contestano), Andrés de la Concha Velasco (del partido o administración de Ávila) y Andrés Pinto de Salinas (posiblemente del marquesado de Las Navas y condado de El Risco, también en tierras abulenses).

Sin embargo, no se les hacía a los tres administradores la misma solicitud y requerimiento en el oficio. Pues, en el caso de los administradores de Ávila, se les instaba a que

todos los papeles auténticos que se allen en sus estados se remitan a el Archivo de S.E. en esta corte. Y en cumplimiento de esta orden he resuelto pase a esa [ciudad] [villa] D. Manuel Antonio Brochero (a quien S.E. ha nombrado por su Archivero) para que, reconociendo los que estén en poder de V.m., disponga entregarlos a dicho don Manuel, sacando recivo y buscando persona que en su compaña los conduzca a esta Corte, en lo que espero no abrá el menor retraso, por combenir así al servicio de S.E. ${ }^{52}$.

Por el contrario, en el caso del administrador del condado de Cocentaina Pedro de Lago, debido a que "no haviendo en el Archivo, que tiene el Conde mi señor en esta Corte, papeles algunos por lo respective a ese estado", lo que se le ordena es que "remita V.m. a esta Casa imbentario de todos los documentos que se conservan en ese Archivo, de qualquier calidad que sean, con individual expresión del contexto de cada uno, y sin que en esta diligencia se padezca el menor atraso" ${ }^{53}$.

Es evidente que estas órdenes del conde, en su ausencia transmitidas a través de los agentes principales de la Casa, surtirían de inmediato el efecto preciso. En consecuencia, muy pronto ya estaban instalados en Madrid los fondos documentales del marquesado de Las Navas, condado de El Risco y aquellos otros referentes al conjunto de propiedades que poseían los Benavides en la ciudad y partido de Ávila ${ }^{54}$, fondos que se añadían a los archivos ya allí depositados de los estados de Santiste-

50 Aparicio Valero, M. ${ }^{a}$ G.: Regalismo borbónico e historia crítica. Las comisiones de archivos: su recopilación documental (1749-1756), Valencia, 2013.

51 Véase ADM, Santisteban, 39-2, exp. 1. Al ocupar en 1734 el trono de Nápoles el infante don Carlos (como Carlos VII de Nápoles, futuro Carlos III de España, símbolo del regalismo), el conde de Santisteban y Cocentaina -por recomendación de la reina Isabel de Farnesio, madre del nuevo rey napolitano-acudió a Nápoles durante cuatro años como tutor del joven monarca y su principal ministro.

$52 \quad$ Ibidem (oficios 2 y 3 ).

53 Ibidem (oficio 1).

54 Véase ADM, Santisteban, 39-2, exp. 2. 
ban del Puerto, Castellar, Malagón y Villalonso, con sus agregaciones respectivas. También poco después se traslada a Madrid, desde la villa de Medellín, la documentación de este condado extremeño, un estado que había obtenido el conde Manuel de Benavides en pleito con los marqueses de Aytona ${ }^{55}$.

Tan solo restaba, por tanto, la incorporación del Archivo condal de Cocentaina emplazado en aquel Palau de la villa cabecera del estado. En este sentido, posiblemente, a raíz de la susodicha orden de 1735, el administrador Pedro de Lago elaborara y remitiera a Madrid el inventario requerido de los fondos. Pero el Archivo continuó en la villa alicantina durante otros dieciséis años más, siendo, por el momento, la única excepción a la agrupación documental puesta en práctica por la Casa -ya para entonces ducal- en el depósito madrileño. Y aún habría que esperar dieciséis años más pues no sería hasta mediados del siglo XVIII, ya durante el gobierno de Antonio de Benavides, II Duque de Santisteban y XIV Conde de Cocentaina, cuando el Archivo Condal contestano tomara rumbo hasta la capital del Reino, allá por noviembre de 1751, y en circunstancias ciertamente excepcionales.

\section{Resistencia del pueblo a la marcha de las escrituras}

Las circunstancias que rodearon a este traslado son ciertamente curiosas de referir, a la vez que ciertamente insólitas, pues no deja aún de sorprendernos. Pues, de los muchos conjuntos archivísticos de la nobleza que hemos estudiado, nunca habíamos visto, para la época en la que se produjeron los hechos, un caso tan claro de oposición a la salida de un archivo de la tierra o lugar que lo había visto nacer. Hasta ahora, todos los fondos nobiliarios que hemos estudiado cambiaron de emplazamiento a libre voluntad de sus dueños, con la sola cortapisa de las circunstancias particu- lares internas a la institución que obligaron a ello y sin que, en ningún caso, se produjera alguna injerencia externa contra tal medida.

El Archivo de Cocentaina, sin embargo, sí hubo de verse envuelto en una gran oposición contra la Casa titular cuando los señores quisieron trasladarlo a Madrid. La propia tardanza de su incorporación ya nos pone en antecedentes.

La fuente que narra estos hechos no procede del propio fondo condal, cosa lógica por otro lado, sino de los papeles manuscritos del erudito contestano Agustín Arques y Jover, fraile mercedario, que narra así las curiosas vicisitudes que rodearon esta transferencia del Archivo Condal a Madrid:

El año de 1751, habiendo pasado a aquella villa [de Cocentaina] el ultimo conde D. Antonio [...], determinó sacarlo clandestinamente de allí y pasarlo a Madrid. Para ello dispuso que una noche á la media noche estubiese en el postigo de Palacio una requa de mulos (machos) que se había alquilado en Yecla. Y para evitar qualquiera oposición que pudiera haber de parte de los vasallos, dispuso para aquella noche (que fue el día 2 de noviembre) una función de comedia, bayle y otras diversiones, y combidó á todos los sujetos principales de Cocentayna; y cuando estaban más engolfados en la diversión, sacaron el Archivo que tenían ya encaxonado de pre-

55 Téngase en cuenta que este estado extremeño acababa de incorporarse a la Casa de Santisteban por vía judicial a través de las sentencias de vista y revista dadas por la chancillería de Granada en 1720 y 1726 respectivamente, que ratificó la Sala de mil y quinientos cuatro años después (ADM, Medellín, 2-9 y 10). 
vención, le cargaron en la requa, y marchó esta á amanecer distante del Condado. Es relacion, que me hizo Vicente Juan Reig, escribano patrimonial, que concurrió a todo lo dicho. Y por la verdad lo firmé en Madrid en 4 de marzo de 1787. Fray Agustín de Arques Jover [rúbrica $]^{56}$.

No dudamos en absoluto de la veracidad de esta narración del Padre Arques, aun cuando fue redactada en nota a pie de página a la resolución de una instancia, en memorial elevado a la Casa Ducal, para que le permitieran el acceso y consulta al Archivo una vez en Madrid, solicitud que no le fue autorizada. El mismo hecho de que, al final de su narración, nombre al escribano Reig como testigo y confidente ${ }^{57}$ reafirma la autenticidad del relato.

Así es que parece evidente que el hecho de tener que distraer al vecindario, con nocturnidad, para poder sacar el Archivo de la villa fue por la oposición que surgiría en el condado, al menos por una buena parte de la sociedad contestana del momento.

En cualquiera de los casos, lo que sí es cierto es que con la llegada del Archivo del condado de Cocentaina a Madrid se clausuraba el ciclo de incorporación y agrupamiento de todos los fondos documentales al Archivo General de la Casa Ducal de Santisteban del Puerto, que se había iniciado en 1720 y desarrollado principalmente por los años treinta, en aplicación de la política de concentración archivística ${ }^{58}$ de los cuantiosos fondos documentales de la Casa repartidos por sus numerosos estados señoriales ${ }^{59}$.

\section{Agregación de los fondos a unidades archivísticas superiores: organización y descripción de la documentación}

El Archivo de la Casa Ducal de Santisteban del Puerto, al que se agrega el del condado de Cocentaina a primeros de noviembre de 1751, tenía su sede en la casa principal o "Casa Grande" que poseía la familia frente a la iglesia de San Pedro el Viejo, con fachadas a las calles Nuncio y Pretil de Santisteban ${ }^{60}$. Esa era la morada de los condes y duques de Santisteban desde mediados del siglo XVI, en que estos Benavides se afincaron en la Corte.

Más adelante, a raíz del enlace matrimonial contraído en 1764 entre la por entonces futura XV Condesa de Cocentaina y III Duquesa de Santisteban del Puerto, Joaquina María de Benavides y Pacheco (heredera de la Casa en 1782) con el también por entonces futuro XIII Duque de Medinaceli y otros títulos ${ }^{61}$, Luis María Fer-

ADM, Santisteban, 39-2, exp. 2.

57 Este Vicente Juan Reig era por entonces, efectivamente, escribano patrimonial de la Casa de Cocentaina (véase ADM, Cocentaina, 25-1).

58 Véase todo el proceso de concentración archivística de los diversos fondos en Sánchez, op. cit. (nota 39), pp. 103-108.

59 Estos duques de Santisteban del Puerto también eran marqueses de Solera (de la Casa "De la Cueva"), condes de Medellín (de los "Portocarrero" extremeños), señores de Villafranca de la Sierra, marqueses de Las Navas y condes del Risco (de la familia "Dávila"), marqueses de Malagón y sus señoríos vinculados de Fernán Caballero y Paracuellos del Jarama (de los “Arias Pardo-Tavera"), condes de Villalonso (de los "Ulloa”), condes de Castellar de la Frontera y señores de El Viso del Alcor (de los “Arias de Saavedra”), además de condes de Cocentaina (de estos "Corella" valencianos).

60 Sobre esta casa-palacio, véase ADM, Santisteban, 28-12 a 30. Véase Sánchez, op. cit. (nota 39), pp. 109-112.

61 Estos duques de Medinaceli eran también duques de Alcalá de los Gazules, marqueses de Tarifa y condes de 
nández de Córdoba y Gonzaga (heredero de su Casa en 1789), se fraguaría la unión de ambas importantes casas nobiliarias españolas y, como consecuencia de ello, se propiciaría la ulterior integración de ambos Archivos generales en un depósito único, con inclusión de la documentación del condado de Cocentaina.

Heredó ambas casas nobiliarias, con sus numerosos títulos y estados agregados, durante los primeros años del siglo XIX a la muerte de sus progenitores (1805 y 1806, respectivamente) -según dijimos- el primogénito de aquel matrimonio, Luis Joaquín Fernández de Córdoba y Benavides (1780-1840), XVI Conde de Cocentaina, XIV Duque de Medinaceli y IV de Santisteban del Puerto.

Así, pasado el convulsivo período de la Guerra de la Independencia española (1808-1814), hasta al Archivo Ducal de Medinaceli -ubicado en el suntuoso palacio que tenían en la confluencia del Paseo del Prado con la Carrera de San Jerónimo- llegó en 1818, desde aquella Casa Grande de la Plaza de San Pedro, la documentación del condado de Cocentaina unida al Archivo de Santisteban del Puerto.

$\mathrm{Y}$, en adelante, el fondo del condado contestano que aquí tratamos ya no abandonaría nunca el Archivo Ducal de Medinaceli hasta nuestros días, radicando sucesivamente tanto en Madrid (1818-1961) como después en la "Casa de Pilatos" de Sevilla (1961-1995) y, por último, en Toledo -desde 1995-, con sede en el Palacio Tavera (antiguo Hospital de San Juan Bautista), donde hoy permanece.

\section{Organización y descripción documental}

El principal artífice inicial de las tareas orgánicas y descriptivas sobre los fondos archivísticos de la Casa de Santisteban del Puerto, al que quedó definitivamente integrado en 1751 el condal de Cocentaina, había sido el primer archivero del depósito de la Plaza de San Pedro, llamado Manuel Antonio Brochero (1735-1773). Así lo hizo con los fondos de los estados agregados a la Casa que habían llegado hasta aquella casa-palacio durante los años 30 del siglo XVIII ${ }^{62}$. Y, aunque su etapa al frente del Archivo de Santisteban se prolongó hasta 1773, sin embargo, él no acometió la organización de la documentación del condado de Cocentaina.

Precisamente, una vez concluida la etapa de Brochero como archivero, el Archivo Ducal de Santisteban quedó reglamentado por la Instrucción dada desde Aranjuez, el 8 de junio de $1773^{63}$, por Antonio de Benavides, XIV Conde de Cocentaina y II Duque de Santisteban, al poco de nombrar nuevo archivero mayor a José Manuel de la Vega (1773-1782) ${ }^{64}$, una fase transitoria en el depósito desde el punto de vista $\operatorname{orgánico~}^{65}$.

los Molares (de los "Enríquez de Ribera", Adelantados mayores de Andalucía), duques de Segorbe y condes de Ampurias (de la casa real de Aragón), duques de Cardona (de los "Folc de Cardona") y sus títulos agregados de marqueses de Pallars, condes de Prades y barones de Entenza, vizcondes de Vilamur, etc., duques de Lerma y marqueses de Denia (de los "Sandoval y Rojas"), marqueses de Santa Gadea (de los "Manríquez de Padilla", adelantados mayores de Castilla), condes de Buendía (de los "Acuña"), entre otros.

62 Véase Sánchez, op. cit. (nota 39), pp. 113-139.

63 ADM, Santisteban, leg. 39 núm. 2 exp. 5: doc. inserto en la ratificación de 26 de marzo de 1799, que tuvo dicha Instrucción). Véase Sánchez, op. cit. (nota 39), pp. 140-144, más transcripción del documento en pp. 269-271.

64 Una comparación de este reglamento con otro del Archivo Ducal de Medinaceli, elaborado el mismo año, en Sánchez González, A.: "Dos desconocidos reglamentos de archivos", Vegueta: Anuario de la Facultad de Geografia e Historia, 16 (2016), pp. 481-506.

65 Este archivero, en realidad, aportó muy poco, Sánchez, op. cit. (nota 39), pp. 131-133. 
Y con el relevo en la jefatura de la Casa de Santisteban-Cocentaina, en 1782, al suceder la XV Condesa Joaquina María de Benavides y Pacheco también debió declinar la gestión de J. M. de la Vega a cargo del Archivo, ascendiendo en el oficio Manuel de Terán (1783-1802), que era oficial del mismo desde $1780^{66}$. Este iba a ser quien acometiera la organización de la documentación del condado de Cocentaina, único fondo pendiente de tratamiento archivístico del depósito, y consecuentemente el artífice de la conclusión y complementariedad de la organización documental del resto de los fondos del Archivo con respecto al estado en que lo había dejado Brochero $^{67}$.

Así, Terán debió dedicarse al Archivo de los antiguos Corella valencianos durante los dos años siguientes, dejándolo plenamente reorganizado antes de $1785^{68}$, pues en mayo de ese año, a petición del Duque-Conde Luis María Fernández de Córdoba, el archivero hubo de realizar un informe sobre su gestión en el conjunto del Archivo y el estado del depósito, del que se desprende muy claramente que todos los fondos se custodiaban ya en papeleras o cajones y que ya él había concluido la organización y descripción de los documentos del condado de Cocentaina. A este respecto, dice literalmente en su informe: "El presente Archibero los ha extratado, imbentariado, enlegajado, puestas sus carteras y colocado con resguardo dentro de las onze papeleras que son las ocupadas con este basto [sic] trabajo"69.

Esta labor orgánica de Manuel de Terán sobre el fondo contestano siguió, en líneas generales, los perfiles y diseños trazados con anterioridad por Brochero para el resto del conjunto documental. Sin embargo, el nuevo archivero introdujo algunas novedades orgánicas consistentes, más que nada, en subsanar algunas de las series muy ambiguas establecidas en la clasificación anterior, delimitando mucho mejor las series territoriales y separando más los fondos particulares de cada uno de los dominios que integraban el condado alicantino, a cuyo nivel de pormenorización no había llegado siempre Brochero en los restantes fondos del depósito de la Casa de Santisteban. Además, Terán fija de forma más precisa series que antes habían quedado ocultas (Vg. apeos y deslindes de términos, penas de cámara, oficios y nombramientos de oficiales, etc.) o que habían sido tratadas de manera irregular (Vg. la serie de posesiones).

Con estos criterios correctores, apenas sustancialmente diferentes a los que ya tenía implantados el Archivo de la Casa en los restantes fondos, inició Manuel de Terán la clasificación de la documentación del condado de Cocentaina. Para ello, prosiguió con la descripción de todas y cada una de las escrituras, cuyas regestas reflejó particularmente en cada una de las carpetillas o guardas y no al dorso de los documentos. Tras quedar las series definitivamente conformadas, con tales grupos documentales homogéneos formó legajos, una vez ordenada y enumerada cada pieza, signatura que no solo reflejó en dichas guardas sino también en los márgenes superiores de los documentos. Estos legajos fueron entonces introducidos seguidamente en las once papeleras o cajones -también numerados y con su rotulata- en las que quedó custodiado el fondo.

\footnotetext{
ADM, Santisteban, 39-2, expds. 5 y 7.

Véase Sánchez, op. cit. (nota 39), pp. 133-139.

ADM, Santisteban, 39-2, exp. 5. El informe completo en Sánchez, ibidem, pp. 272-273 (núm. 8 del apéndice documental).
}

69 Ibidem. 
El resultado de la tarea organizativa de Manuel de Terán se refrendó en la elaboración del inventario de la sección, que recibió el título de Libro del Estado de Cocentaina [s.f. (1780-1784)] y, aunque no lleva su nombre, es autógrafo suyo. Está compuesto por tres tomos, con formato de marca mayor, encuadernados al clásico estilo barroco en tafilete granate con decoración floral y grecas grabadas en oro fino, y sin broche de cierre.

Precede al tomo I, que consta de 580 folios, un escudo con las armas de los Corella pintado sobre pergamino a color y un índice de materias en las que queda estructurado el inventario. El tomo II, que se dedica a las heredades de los términos del condado, se compone de 560 folios y, como el anterior, aparte de precederle un índice de materias, presenta muchas hojas en blanco al final de las descriptoras de cada serie. Y el tomo III queda precedido por una somera explicación del contenido específico de esta parte del inventario, dedicada exclusivamente a censos, sin ningún índice de materias; consta este tomo de 554 folios, quedando sin descriptores a partir del 500 .

El inventario es muy parecido a los que ya tenía el Archivo para el resto de las secciones, elaborados por Brochero varias décadas atrás, con alguna excepción ${ }^{70}$. La ratio ordinis que distingue y encauza el inventario de Terán es exactamente la misma, con la única diferencia de que ya se refleja el número de cajón en la signatura. Las regestas, como las anteriores, son muy extensas por lo general; no tiene el inventario el capítulo "Asientos Generales", explicativo de las rentas, regalías, patronatos, etc., del condado, y sí, como los anteriores, un árbol genealógico final, aunque este fue arrancado al manuscrito con posterioridad.

La labor de Terán, sin embargo, no se limitó exclusivamente a la organización de la documentación del condado de Cocentaina, sino que además -según manifestamos en otros trabajos nuestros de reciente aparición- revisó los fondos de otras parcelas del conjunto del Archivo General de la Casa de Santisteban ${ }^{71}$, tarea de revisión y nueva descripción emprendida probablemente en la última década del siglo XVIII ${ }^{72}$.

Como ya hemos puesto de manifiesto en alguna ocasión ${ }^{73}$, podemos calificar solo de aceptable la valoración final del trabajo orgánico realizado por Manuel de Terán con los fondos del Archivo ${ }^{74}$. Valgan nuestras palabras ya vertidas cuando

70 La mayor diferencia entre ambos instrumentos de descripción archivísticos estriba en que éstos de Terán no se estructuran como doble inventario, dejando la segunda parte del tomo para futuras ampliaciones, entendiendo el nuevo archivero que las previsiones de su antecesor en tal sentido habían sido exageradas. Para ello, la solución que estableció Terán fue dejar mayor número de folios en blanco al final de cada serie, respecto a los que había dejado Brochero.

71 En concreto, los fondos del estado de La Navas y señorío de Villafranca, los del marquesado de Malagón y señorío de Paracuellos, y los del estado de Castellar. De algunos de estos fondos ya nos hemos ocupado particularmente. Véanse, por ejemplo, Sánchez González, A.: "El Archivo de los Condes de Castellar, alfaqueques mayores de Castilla", Chronica Nova, 46 (2020), p. 367; "El Archivo de los mariscales de Castilla, marqueses de Malagón", Espacio, Tiempo y Forma - Serie III: Historia Medieval, 34 (2021, en prensa); "El Archivo señorial de Paracuellos, fondo documental de los marqueses de Malagón”, Vínculos de Historia, 10 (2021, en prensa).

72 Carta de M. de Terán al duque en la que le manifiesta sus inconvenientes para "una noticia la más exacta de los papeles de las Navas". Madrid, 23 junio 1792, ADM, Santisteban, 39-2, exp. 5.

73 Véanse Sánchez, op. cit. (nota 39), p. 138 y Sánchez, op. cit. (nota 71, 2020) p. 368.

74 Buena prueba de ello es que el plan orgánico global del Archivo de Santisteban sería cuestionado después, y parcialmente modificado, por un nuevo archivero, en un intento de adaptación al sistema implantado en el Archivo de la Casa de Medinaceli. 
nos referíamos a la ayuda que le prestó Juan Antonio Casas, oficial mayor del Archivo, en un centro como el de la plaza de San Pedro que había modificado parcialmente por entonces su horario laboral adelantando las horas de la tarde para evitar así el riesgo de incendios con los braseros dispuestos en aquellas salas ${ }^{75}$. Con la vacante de oficial, por fallecimiento de Casas en 1792, y los problemas que ello generó, el archivero Terán dirigió escrito al duque el 8 de mayo de ese mismo año comunicándole que el trabajo archivístico no podía hacerlo un hombre solo "... sin el auxilio de uno que le escriba a la mano con conocimiento del idioma latino [...] $y$ de un sujeto inteligente en los caracteres antiguos"76. La petición surtió efecto pues el día 1 de junio inmediato era nombrado Bonifacio Arengo oficial mayor del Archivo, contando también con la ayuda añadida de algunos copistas, al menos durante el año $1795^{77}$.

Traspasado el umbral del siglo XIX, entre los años 1805 y 1806 la Casa de Santisteban del Puerto queda definitivamente vinculada a la de Medinaceli en la persona del heredero Luis Joaquín Fernández de Córdoba y Benavides, doble duque por tales títulos y XVI Conde de Cocentaina. Consecuencia de la unión de esas dos importantes casas nobiliarias, tras la convulsa etapa vivida por la familia a raíz de la Guerra de la Independencia (con obligado retiro a Ceuta durante los años de la contienda), como desarrollamos en diversos trabajos, se juntaron también ambos Archivos - ubicados en Madrid en sus sedes respectivas- con la transferencia del de Santisteban al de Medinaceli, situado en el grandioso palacio que estos últimos tenían en el paseo del Prado $^{78}$. La orden ducal para el traslado se dio el 4 de abril de 1818, quedando el depósito bajo la dirección técnica única del archivero Juan Gil de Arana ${ }^{79}$. Dentro del palacio del Prado, la documentación llegada desde el pretil de San Pedro ocupó una dependencia aparte, aledaña al antiguo depósito.

Más adelante, durante las últimas décadas del propio siglo XIX, se consuma la organización global de los fondos del unificado Archivo madrileño y su descripción general. De ese modo, en el recuento total ${ }^{80}$ realizado en 1886 por el archivero-bibliotecario de los duques de Medinaceli José María Octavio de Toledo ${ }^{81}$, el fondo concreto del condado de Cocentaina estaba custodiado en 8 papeleras enumeradas

ADM, Santisteban, 39-2, exp. 6: decreto de 9 febrero 1791. Véase Sánchez, "El Archivo de los Condes de Castellar...", op. cit., p. 368.

76 ADM, Santisteban, 39-2, exp. 4.

77 Fueron los casos de Antonio Soldevilla y Ategui, nombrado copista el 6 de enero, y Joaquín de Mohíno, nombrado el 25 de diciembre de ese año de 1795. Sirvieron, además, como porteros de la Contaduría y Archivo de la Casa, por entonces, Pedro Blanco -desde el 20 de diciembre de 1791-y Bartolomé Angulo - desde el 10 de noviembre de 1794- (ADM, Santisteban, 39-2, exp. 9), quienes recibieron precisas instrucciones sobre sus cometidos por parte del mismo duque a través del secretario Cayetano Rodríguez de Mora por orden de 24 de enero de 1792 (ADM, ibidem).

78 Palacio edificado por el primer duque de Lerma y luego ampliado por los Medinaceli. Más datos sobre este traslado en Sánchez, op. cit. (nota 39), pp. 149-160, "El Archivo de los Condes de Medellín, reposteros mayores del rey de Castilla", Revista General de Información y Documentación, 30-1 (2020), p. 90 y Sánchez, op. cit. (nota 71, 2020), p. 369.

79 Arana fue un leal servidor de la Casa que defendió los Archivos y todo el patrimonio ducal como si fuera suyo durante los difíciles años de la guerra de la Independencia [véase Sánchez, op. cit. (nota 39), pp. 152-167].

80 El Archivo Ducal de Medinaceli, en su conjunto, estaba entonces integrado en 42 secciones, con 3.864 legajos, 502 libros y 37 documentos sueltos, que se custodiaban en las 460 papeleras del depósito.

81 Véanse Sánchez González, A.: El Archivo de los Adelantados de Andalucía (Casa de Alcalá). Sevilla: Universidad de Sevilla, 2014, p. 97, Sánchez, op. cit. (nota 78, 2020), p. 90 y Sánchez, op. cit. (nota 71, 2020), p. 369. 
correlativamente (dos de ellas vacías), con 60 legajos y cinco documentos sueltos, tal como queda recogido aquí.

Tabla 2. Disposición del fondo del Condado de Cocentaina en el Archivo Ducal de Medinaceli, 1886 (Fuente: ADM, “Archivo Ducal. Leg. 14")

\begin{tabular}{|c|c|c|c|c|}
\hline Signatura & Series & $\begin{array}{l}\text { N }^{0} \text { LEGA- } \\
\text { JOS }\end{array}$ & $\begin{array}{l}\mathbf{N}^{0} \text { DoCs. } \\
\text { SuEltos }\end{array}$ & $\begin{array}{l}\text { No }^{0} \text { LI- } \\
\text { BROS }\end{array}$ \\
\hline Papelera $1^{\mathrm{a}}$ & $\begin{array}{l}\text { Cuatro papeles sueltos, tres manuscritos } \\
\text { y uno impreso impreso }\end{array}$ & & 4 & \\
\hline Papelera $2^{\mathrm{a}}$ & $\begin{array}{l}\text { Papeles pertenecientes a la villa de Co- } \\
\text { centaina y lugares del condado (Leg. } 1 \text { á } \\
\text { 16) }\end{array}$ & 16 & & \\
\hline Papelera $3^{\text {a }}$ & Idem (Leg. 17 á 29) & 13 & & \\
\hline Papelera $4^{\mathrm{a}}$ & ---Vacía--- & & & \\
\hline Papelera $5^{\mathrm{a}}$ & $\begin{array}{l}\text { Papeles pertenecientes a la villa de Co- } \\
\text { centaina y lugares del condado (Leg. } 30 \\
\text { á } 45 \text { ) }\end{array}$ & 16 & & \\
\hline Papelera $6^{\mathrm{a}}$ & Idem (Leg. 46 á 54) & 9 & & \\
\hline Papelera $7^{\mathrm{a}}$ & Idem (Leg. 1 á $5^{\circ}$, el $4^{\circ}$ duplicado) & 6 & & \\
\hline Idem & Un rollo de pergamino & & 1 & \\
\hline Papelera $8^{\mathrm{a}}$ & 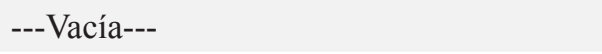 & & & \\
\hline
\end{tabular}

Como también hemos puesto de manifiesto en otras ocasiones, en el Archivo ducal se había implantado el nuevo ciclo archivístico que nosotros hemos dado en llamar de la "Desvinculación señorial" entre la alta nobleza española del momento. Este nuevo ciclo acarreó una serie de cambios en los depósitos archivísticos del Archivo ducal de los Medinaceli en aspectos tales como el sistema de instalación documental, un reajuste de sus secciones y la elaboración de nuevos instrumentos de descripción ${ }^{83}$.

Así, con respecto al modo de instalación documental, la modificación sustancial consistió en la sustitución de las antiguas y herméticas papeleras del Archivo por legajos colocados en estanterías abiertas ${ }^{84}$, modificándose con ello la tradicional reconditez y el carácter arcano que habían caracterizado a los fondos durante el Antiguo Régimen por este sistema más abierto y perceptible. Dicho cambio se produjo a fines del siglo XIX y lo materializaron los archiveros Julián Paz (1892-1895) y Antonio Paz y Mélia (1895-1926), hijo y padre respectivamente y ambos miembros del cuerpo de Archiveros, Bibliotecarios y Anticuarios españoles, el último además jefe del Departamento de Manuscritos de la Biblioteca Nacional.

\footnotetext{
82 Se trata del período que arranca con la abolición de los mayorazgos y de los señoríos jurisdiccionales, que coincide con la entrada del régimen político del liberalismo en España, en el que la nobleza sufre una gran transformación que afectó también a sus Archivos.

83 Véanse Sánchez, op. cit. (nota 39), pp. 104-109, Sánchez, op. cit. (nota 78, 2020), pp. 91-92, Sánchez, op. cit. (nota 71, 2020), p. 371 y "El Archivo señorial de los Adelantados de Castilla", Documenta \& Instrumenta, 19 (2021), p. 239.

84 Esos legajos son los mismos que hoy se conservan.
} 
Entonces se mantuvo la sección "Cocentaina" que aquí nos ha ocupado, con 35 legajos como hoy, cuya estructura queda de manifiesto en el cuadro de clasificación del antiguo fondo recogida seguidamente.

Tabla 3. Cuadro de clasificación de la documentación del Condado de Cocentaina

1. GESTIÓN DE LA DOCUMENTACIÓN

1.1. Apuntamientos: informes de los archiveros y decretos del Archivo

2. DESCENDENCIA Y SUCESIÓN

2.1. Fundaciones y agregaciones de mayorazgos. Testamentos

2.2. Curadurías y particiones de bienes

2.3. Dispensas y legitimaciones

2.4. Dotes, arras y capitulaciones matrimoniales

2.5. Posesiones

3. PATRIMONIO

3.1. Títulos o pruebas de dominio y jurisdicción del condado y lugares de su término

3.2. Villa de Cocentaina (Alicante)

3.3. Lugar de Planes y aldeas de su término

3.4. Lugar de Muro

3.5. Lugar de Turballos

3.6. Lugar de Gayanes

3.7. Lugar y baronía de Penella

3.8. Lugar de Fraga, arrabal de Cocentaina

3.9. Lugar de Alcudia o Benimarfull

3.10. Lugares de Benitaer, Benamer y Benifit

3.11. Pertenencias en diversas poblaciones, dentro y fuera del condado

3.12. Antiguas posesiones de la Casa de Corella en España e Italia

4. OFICIOS Y DIGNIDADES

4.1. Virreinatos de Valencia y Nápoles, embajada en la Santa Sede, cargo de camarlengo de Sicilia

4.2. Encomiendas

4.3. Juramentos de oficiales del condado

5. PATRONATOS, BENEFICIOS, CAPELLANÍAS, CURATOS Y OBRAS PÍAS

5.1. En Cocentaina: Iglesia parroquial, convento del Milagro, convento de San Sebastián, hospital del Corpus Christi, capellanías y obras pías varias

5.2. Iglesia parroquial de San Juan Bautista de Muro

5.3. Bulas eclesiásticas concedidas a los condes y memorias fundadas por estos señores fuera del condado 


\section{DOCUMENTACIÓN DE RECUENTO Y CONTROL}
6.1. Inventarios de bienes.
6.2. Cabreves
6.3. Inventarios de escrituras

7. CONTABILIDAD
7.1. Diezmos
7.2. Censos
7.3. Cuentas y libros de rentas
7.4. Relaciones de débitos

8. PLEITOS

8.1. Por la sucesión del mayorazgo de Almenara, principado de Melito y ducado de Francavilla

8.2. Por la sucesión de las pertenencias de los condes de La Puebla en la villa de Magaña (Soria)

8.3. Sobre cabrevaciones en los lugares de Muro, Gayanes y Turballos

8.4. Sobre dotes

8.5. Causas y procesos criminales

8.6. Causas y procesos civiles

9. VARIOS

9.1. Ápocas, órdenes de los condes, arrendamientos, décimas, pago de sisas, poderes, etc.

Así estructurada es como se ha transmitido hasta nuestros días, dentro del Archivo de la Fundación Casa Ducal de Medinaceli, la documentación del condado de Cocentaina.

\section{Conclusiones}

Realmente las escrituras de aquel antiguo estado señorial, que guardaban la memoria de siglos de toda una comarca levantina llamada hasta nuestros días Comtat por aquel condado, parece que mereció la resistencia de una parte de la sociedad del siglo XVIII que pretendía que el Archivo de sus condes permaneciera en el lugar que vio nacer o guardar esos documentos.

Para dilucidar este caso, no parece suficiente con afirmar -como aquí hemos hecho hasta ahora- que este insólito hecho se explica porque la gente de aquel condado quería mantener cerca su legado histórico. Lo normal, en estas situaciones, ha sido siempre justo lo contrario, es decir, la destrucción de los archivos o de los documentos justificativos de los derechos y privilegios de los poderosos, sobre lo que se conoce un amplio muestrario. Habría que ir entonces más allá pues debieron conjugarse otros factores para explicar esa oposición en Cocentaina a la marcha del archivo de la villa condal.

Sin embargo, no tenemos pruebas documentales que nos den luz al respecto. De ahí que, entrando en el terreno de la conjetura, solo podamos afirmar que también se justificaría esa contraria posición a los intereses del conde por el hecho de que a la 
oligarquía local contestana le interesara la cercanía de esos documentos como garantía de derechos, dado que no parece que la oposición a la salida del archivo partiese de toda la población sino solo de sus habitantes "principales". De hecho, la descripción del suceso por el padre Arques -a instancia de la relación que a posteriori le hizo el escribano patrimonial del condado Vicente Juan Reig, testigo de todo lo referido- precisa que el conde "combidó a todos los sujetos principales de Cocentayna" a aquella ceremonia de la distracción que posibilitó la marcha del archivo a Madrid. Conviene añadir, además, que siendo fray Agustín de Arques archivero general de la Orden de la Merced y queriendo consultar el Archivo del condado de Cocentaina una vez en Madrid, por los años 80 del siglo, los condes le impidieron el acceso, lo que contrarió al mercedario pues había nacido en aquel estado levantino y se encontraba escribiendo una historia de la patrona de la villa, Nuestra Señora del Milagro.

Primó, finalmente, la decisión archivística de la concentración documental por encima de cualquier otro considerando, aunque debieron transcurrir dieciséis años desde la inicial resolución condal genérica, en 1735, de traslado a la Corte de todos los archivos de la Casa de Santisteban que aún no lo habían hecho, hasta la ejecución efectiva de la orden -para el caso de Cocentaina en 1751-, al ser el único archivo que se resistió al mandato, si bien es cierto que en aquella primera orden lo que se le requirió al administrador del condado fue, excepcionalmente con respecto a todos los demás casos, solo el inventario de la documentación del estado alicantino.

El antiguo fondo documental contestano, está compuesto por varios centenares de diplomas que se custodian hoy mayoritariamente en esos 35 legajos del Archivo de la Fundación Casa Ducal de Medinaceli, más diferentes pequeñas series y piezas sueltas distribuidas en otras secciones del depósito -referidas principalmente a dominios señoriales con los que los Corella valencianos tuvieron relación de parentesco-como las de "Las Navas" y "Santisteban", al igual que en la miscelánea conocida como "Archivo Histórico". También en la sección "Segorbe" del Archivo Ducal hay un fondo medieval de Cocentaina, referente al período en que la entonces baronía perteneció a los infantes de la Casa real de Aragón-Barcelona ${ }^{85}$.

Ya en la etapa del archivero Paz y Mélia, durante los últimos años del siglo XIX y primeras décadas del XX, se incluye en la referida sección "Archivo Histórico" la serie documental del condado de Cocentaina relativa a reales cédulas y provisiones de concesión de títulos y otros privilegios y mercedes dadas por los soberanos a los titulares del estado, como también la correspondencia real y particular de algunos condes de aquel dominio alicantino. Igualmente pasó a esta misma miscelánea histórica del Archivo Ducal abundante correspondencia de valija diplomática de determinados condes de Cocentaina y duques de Santisteban del Puerto ${ }^{86}$, además de otra documentación y correspondencia sobre funciones gubernativas desempeñadas por algunos de estos nobles en América, Italia, etc ${ }^{87}$. Parte de esta documentación ya ha sido dada a conocer por nosotros mismos en otros trabajos, si bien en aspectos parciales ${ }^{88}$, estando pendiente la realización de una obra de conjunto sobre este condado levantino.

85 Véase ADM. Segorbe (antiguo patrimonio), legs. 76 a 78, 80 y 120 a 122, con docs. del período 1280-1325.

86 De los Condes Manuel y Antonio de Benavides, I Duque y II Duque de Santisteban del Puerto, respectivamente. Véase ADM, Archivo Histórico, leg. 80 núms. 49-74.

87 ADM, Archivo Histórico, leg 74, núms. 10 a 15, y leg. 75, núms. 1 a 40, más leg. 80, ramo 24, núms. 1 a 28.

88 Por ejemplo, del conde que fue virrey del Perú [véase Sánchez González, A.: "Papeles de ida y vuelta del virrey del Perú Diego de Benavides (1660-1666)", en El Archivo General de Indias: El valor del documento y la escritura en el gobierno de América, Madrid: Ministerio de Cultura, 2016, pp. 239-250]. 
Del antiguo fondo contestano, el Archivo de la Casa Ducal de Medinaceli conserva aún como útil instrumento de descripción el inventario del siglo XVIII conocido como Libro de Estado de Cocentaina, obra del archivero Terán y memoria de cuando se organizó la mayor parte de la documentación de aquel estado, además de las fichas catalográficas realizadas por Paz y Mélia, también muy útiles, que se conservan aún. El propio sistema orgánico que se fijó en este fondo levantino -como en el resto del Archivo-, con la documentación descrita, pieza a pieza, en las guardas o carpetillas de cada documento, en labor realizada por los distintos archiveros que llevaron a cabo el trabajo orgánico y corregida y completada después por el propio Paz y Mélia, ayuda a la identificación y conocimiento del contenido de toda la documentación relativa al condado.

Sirva también de contribución al conocimiento de este antiguo fondo, la guía incluida por nosotros aquí, como Apéndice final, con descripción de las series, las fechas extremas y la signatura de localización de los documentos, como humilde aportación para quienes necesiten consultar el archivo señorial contestano que aquí nos ha ocupado.

Coincidencias del destino, dos siglos y medio después de aquella noche del 2 de noviembre de 1751 en la que el archivo puso rumbo a Madrid, esta misma documentación -si bien integrada dentro del Archivo General de la Fundación Casa Ducal de Medinaceli del que forma parte- volverá a conocer una gran resistencia, en este caso de una buena parte de la sociedad sevillana, cuando a fines de septiembre de 1995 el Archivo abandonó su sede hispalense de la Casa de Pilatos para encaminarse al Palacio Tavera (antiguo Hospital de San Juan Bautista) en la ciudad de Toledo, donde hoy permanece custodiado en unas instalaciones envidiables.

Ahí se encuentran, junto al Archivo de la Nobleza, las escrituras de aquellos antiguos condes que contribuyeron tanto a la expansión mediterránea de la Corona de Aragón, del pueblo que se agitó en movimientos antiseñoriales, de la memoria de las luchas, persecuciones y resistencias de minorías como los moriscos, de creencias en prodigios de una Virgen milagrosa y de tantos otros temas aún por desvelar. Todo un acervo documental que transmite el rico pasado de una comarca por la que se rebeló un pueblo, y sobre el que aquí hemos tratado con el objetivo de contribuir al mayor conocimiento de ese pasado.

\section{Bibliografía}

Bonincontri, L.: Historia Regni Neapolitani, libri X. BHUV., mss. nº 689, S. XV.

Cristini, V. y Martella, F.: "Palacio condal de Cocentaina, Alicante (1979-2013)", en Mileto, C. y Vegas, F. (eds.), La restauración de la tapia en la Península Ibérica: criterios, técnicas, resultados y perspectivas, Valencia: TC Cuadernos, 2014, pp. 186-189.

Cuartero Huerta, B. y Vargas Zúñiga, A. de -Marqués de Siete Iglesias-: Índice de la Colección de don Luis de Salazar y Castro. 49 vols. Madrid, 1958-1974.

Diago, F.: Anales del Reyno de Valencia. Valencia: en casa de Pedro Patricio Mey, 1613.

Escolano, G.: Décadas de la historia de la insigne y coronada ciudad y Reino de Valencia / por el licenciado Gaspar Escolano...; aumentada... y continuada hasta nuestros dias por Juan B. Perales. Valencia: Impr. a cargo de Carlos Verdejo; Madrid: Terraza, Aliena y Compañía, 1878-1880.

Facio, B.: Historia de Alfonso V. Lyon, 1560. 
Ferrer i Marset, P.: El Comtat. Una terra de castells. Cocentaina: Centre d'Estudis Contestans, 1996.

Fullana Mira, L.: Los Virreyes de Valencia. [Valencia, 1916].

- Historia de la villa y condado de Cocentaina. Valencia, 1920.

Gaite Pastor, J.: "El sistema de archivos de la administración central española", Revista General de Información y Documentación, vol. 9, 2 (1999), pp. 127-136.

Hernández Guardiola, L.: "Las pinturas de la sala daurada del Palau Comtal de Cocentaina", Alberri: Quaderns d'investigacio del Centre d'estudis contestants, 20 (2010), pp. 203-216.

Jaén i Urban, G. (dir.): Guía de Arquitectura de la Provincia de Alicante. Alicante: Instituto de Cultura Juan Gil-Albert, Colegio Territorial de Arquitectos de Alicante, 1999.

López Gómez, P.: “Archivística y archivos en España. De práctica tradicional a teoría científica”, Archivní časopi, 65 (2015), pp. 1-25. URL: http://hdl.handle.net/2183/15635, fecha de consulta: 26/11/2020).

— "Política archivística y concentraciones de archivos en España, en el siglo XVIII", en Vaquinhas, N.; Caixas, M.; Vinagre, H., Da produção à preservação informacional: desafios e oportunidades, Évora: Cidehus, 2017, pp. 56-76. URL: https://books.openedition. org/cidehus/2645?lang=es, fecha de consulta: 26/11/2020).

López Rodríguez, C.: Nobleza y poder político en el reino de Valencia (1416-1446). Valencia: Universitat de València, 2005.

Martín de Viciana, R.: Chronica de la ínclita y coronada ciudad de Valencia y de su reino. Valencia, 1564, $2^{\mathrm{a}}$ parte (edic. de 1972).

Mateu Ibars, J.: Los Virreyes de Valencia. Fuentes para su estudio. Valencia: Ayuntamiento de Valencia, 1963.

Nadal, V.: "Una vila fortificada: les muralles medievals de Cocentaina", en Cocentaina: arqueología y museo: Museos Municipales en el MARQ, [catálogo de exposición, MARQ, octubre 2015 - febrero 2016], 2015, pp. 230-241.

Pellicer de Tovar, J.: Memorial de Diego de Benavides al rey. Madrid, 1640.

Pla Alberola, P.J.: "Los movimientos migratorios en el condado de Cocentaina tras la expulsión de los moriscos", en Estudis sobre la població del País Valencià: Actes de les I Jornades d'Estudi sobre la Població del País Valencià, vol. 1, 1988, pp. 301-314.

— "Las rentas señoriales del condado de Cocentaina en vísperas de la expulsión de los moriscos”, en Actas del V Simposio Internacional de Mudejarismo, 1991, pp. 275-288.

— "El régimen municipal en las cartas pueblas del condado de Cocentaina, 1611", Dels furs a l'estatut: Actes del I Congrés d'Administració Valenciana, de la Història a la Modernitat, Valencia, 1992, pp. 511-517.

Richart Gomá, J.: Los Corella, Condes de Cocentaina. Memoria histórica de su linaje (Siglos XIII- XVII). Alcoy: Ayuntamiento de Cocentaina, 2019.

Riol, S. A.: Noticia general de todos los archivos y papeles pertenecientes a los Consejos y Audiencias de España. Madrid, 1726.

Ryder, A.: El reino de Nápoles en la época de Alfonso el Magnánimo. Valencia, 1987, pp. 8284. Salazar y Castro, L. de: Historia genealógica y heráldica de la Casa de Lara. Tomo III. Madrid: Imprenta Real, 1697.

Sánchez González, A.: El Archivo de los Adelantados de Andalucía (Casa de Alcalá). Sevilla: Universidad de Sevilla, 2014.

- El Archivo de los Caudillos Mayores del reino de Jaén (Casa de Santisteban del Puerto). Jaén: Instituto de Estudios Giennenses, 2015.

— "Dos desconocidos reglamentos de archivos", Vegueta: Anuario de la Facultad de Geografía e Historia, 16 (2016), pp. 481-506. 
— "Papeles de ida y vuelta del virrey del Perú Diego de Benavides (1660- 1666)", en El Archivo General de Indias: El valor del documento y la escritura en el gobierno de América, Madrid: Ministerio de Cultura, 2016, pp. 239-250.

— "El Archivo de los Condes de Medellín, reposteros mayores del rey de Castilla", Revista General de Información y Documentación, 30 -1 (2020), pp. 75-100.

— "El Archivo de los Condes de Castellar, alfaqueques mayores de Castilla", Chronica Nova, 46 (2020), pp. 347-379.

— "El Archivo señorial de los Adelantados de Castilla", Documenta \& Instrumenta, 19 (2021), pp. 213-246.

— "El Archivo de los mariscales de Castilla, marqueses de Malagón", Espacio, Tiempo y Forma - Serie III: Historia Medieval, 34 (2021, en prensa);

- "El Archivo señorial de Paracuellos, fondo documental de los marqueses de Malagón", Vínculos de Historia, 10 (2021, en prensa).

Silvestre Pérez, S.: El procés repoblador postmorisc al comtat de Cocentaina: entre la mobilitat i la consolidació. Tesis Doctoral: Universidad de Valencia, 2019.

Vidal Bernabé, I.: "Patronato de los condes de Cocentaina en el convento de la Virgen del Milagro", en Patronos, promotores, mecenas y clientes: VII CEHA, Murcia: Universidad de Murcia, 1992, pp. 403-412.

Vidania, D. V. de: Memorial de Francisco de Benavides al rey de los servicios de su Casa. Nápoles: Imprenta de D.A. Parrino y M.L. Mucio, 1696.

Zurita, J.: Anales de la Corona de Aragón. Zaragoza: Lorenzo de Robles, impresor, 1610-21 (Edic. Instituto “Fernando el Católico”, Zaragoza, 1970-1975). 


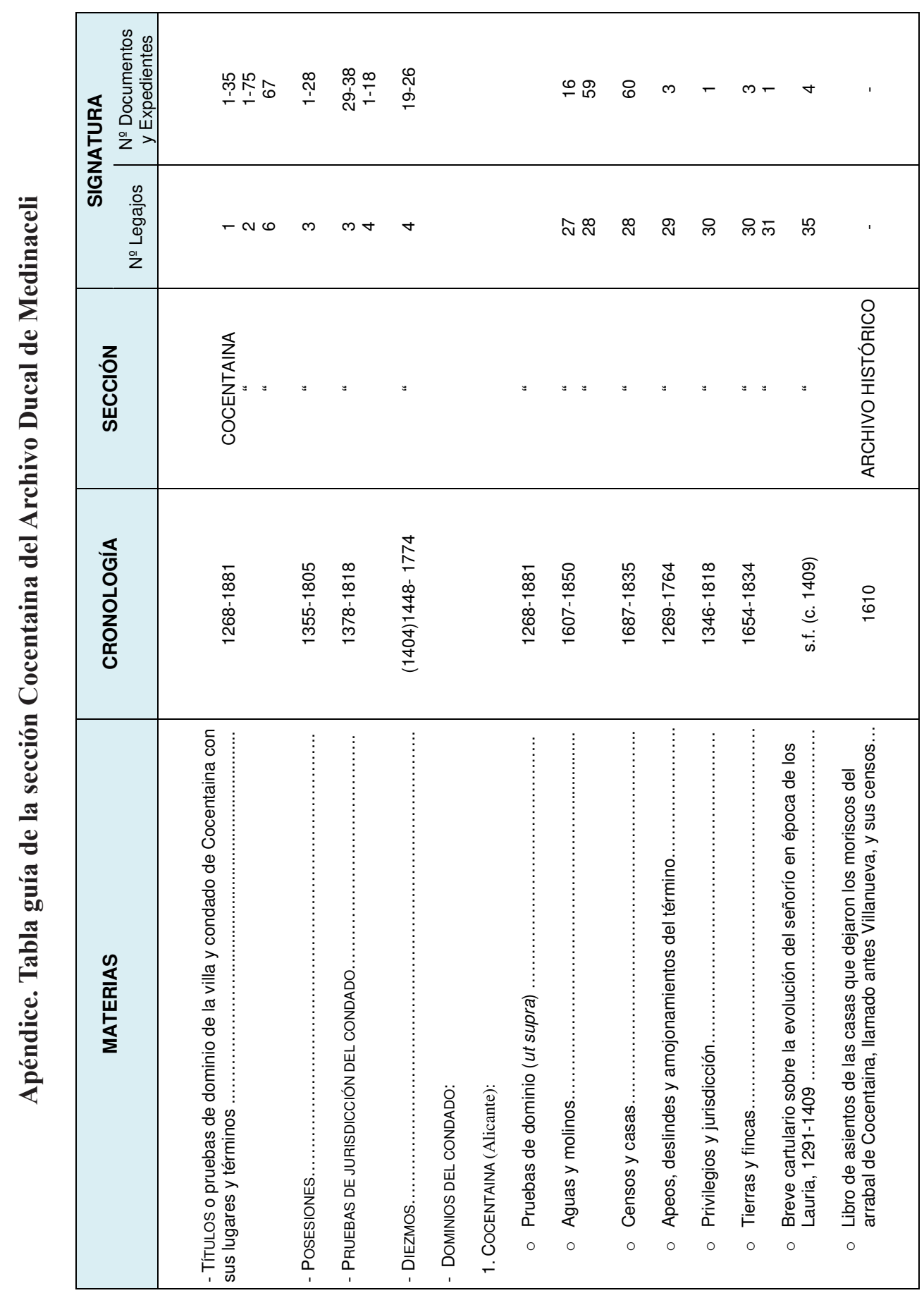




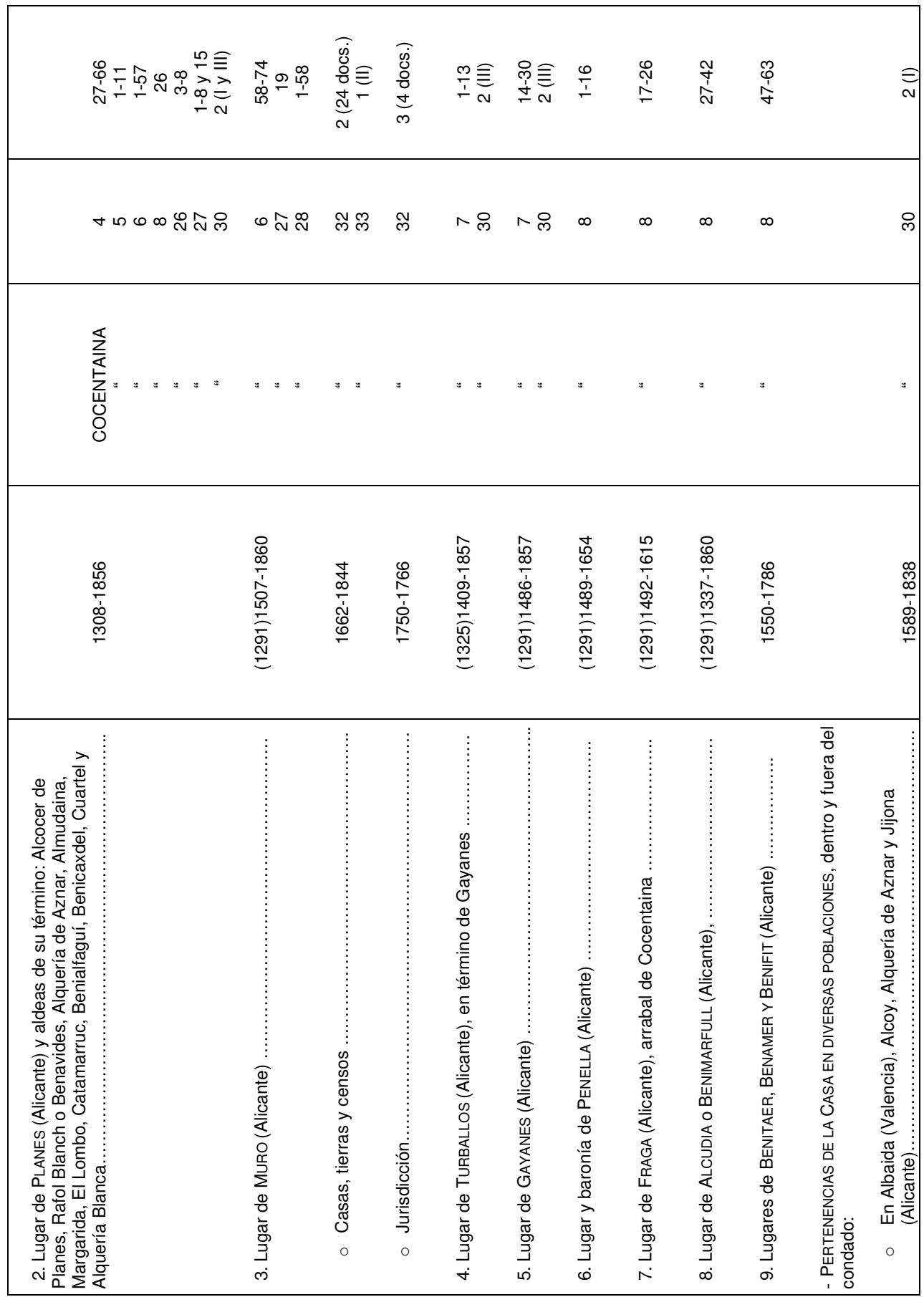




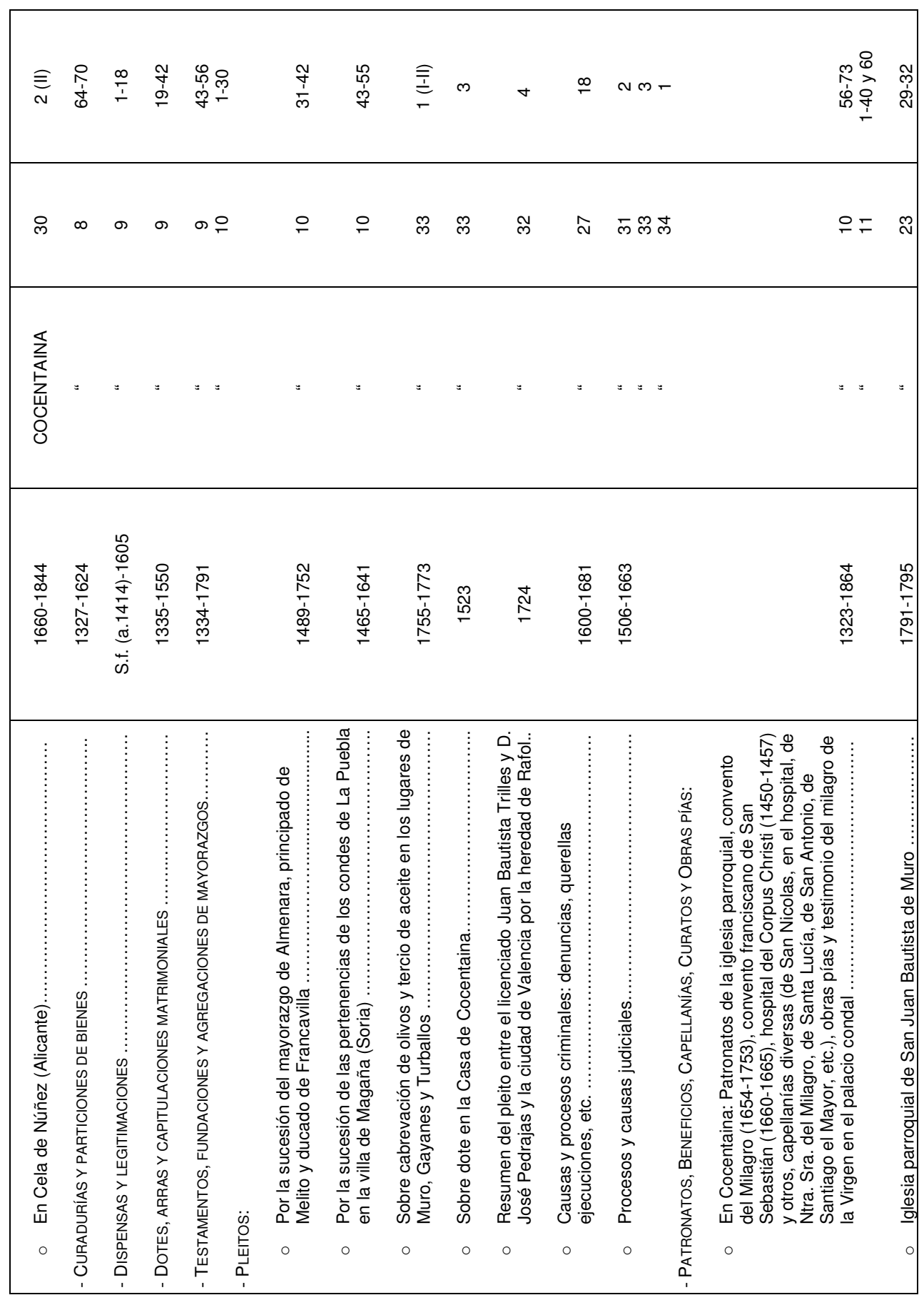




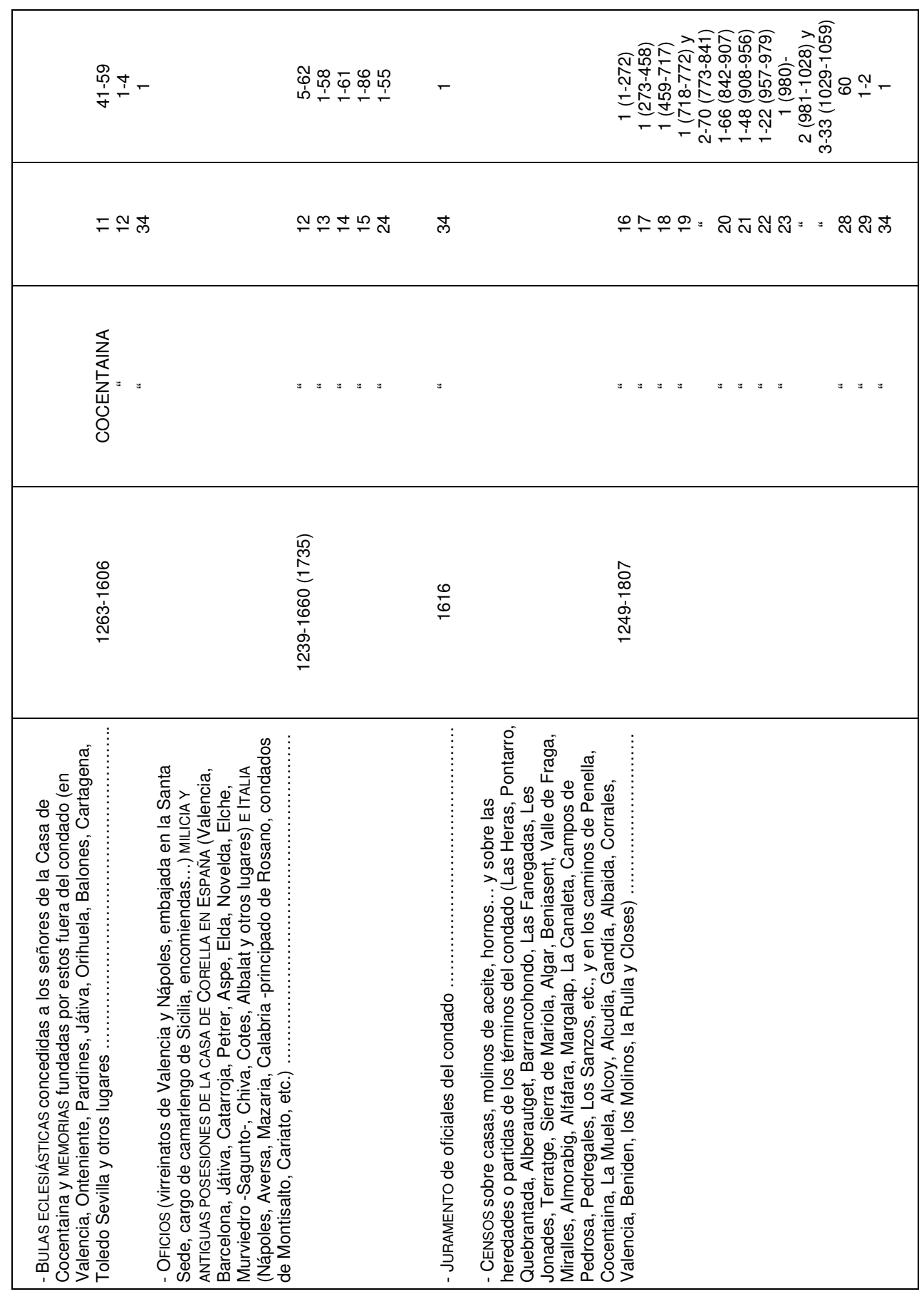




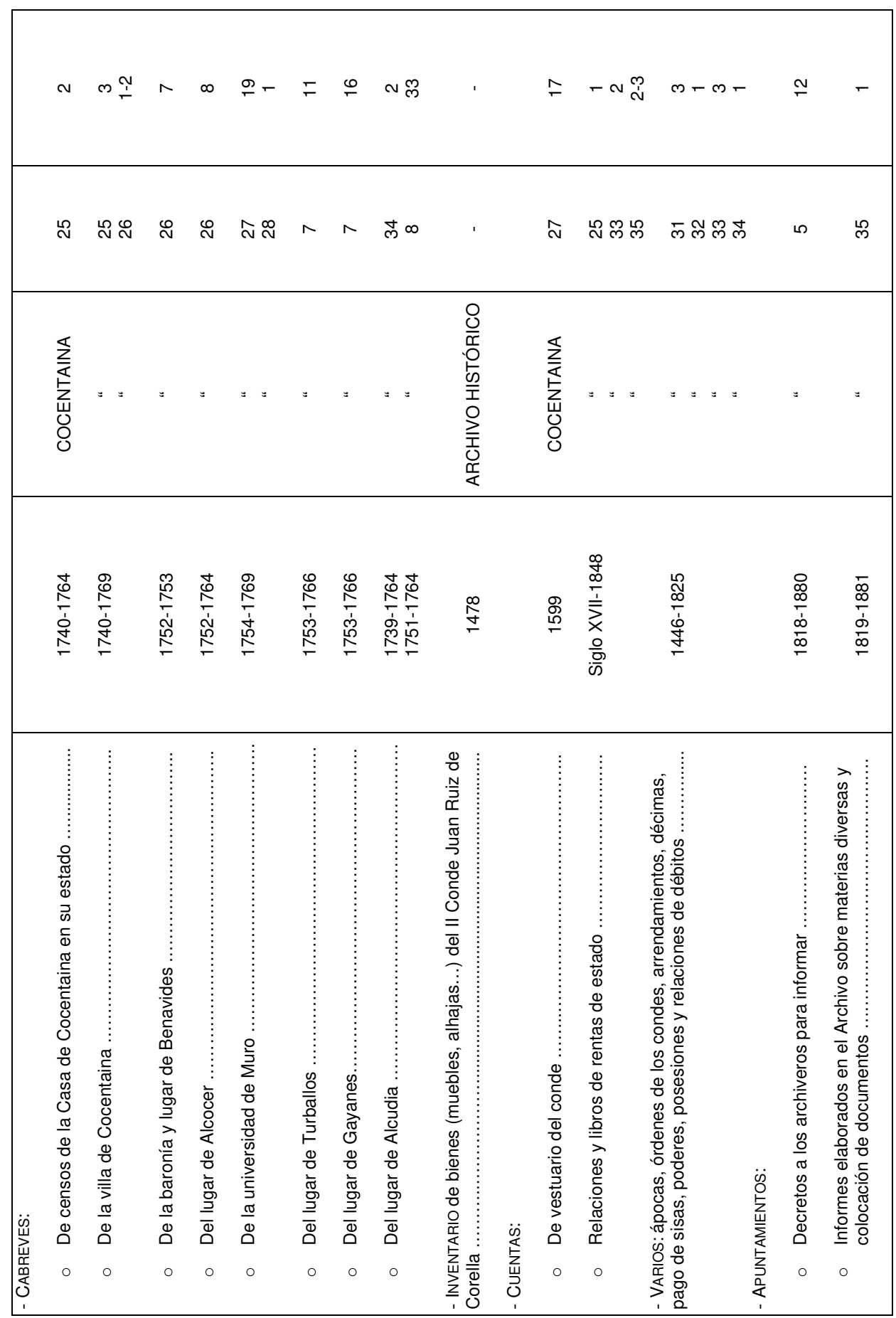

